\title{
Symbiogenesis, gradualism, and mitochondrial energy in eukaryote evolution
}

\author{
WILLIAM F. MARTIN \\ University of Düsseldorf, Universitätsstr. 1 \\ 40225 Düsseldorf, Germany \\ Correspondence: \\ William F. Martin \\ E-mail: bill@hhu.de
}

Keywords: Endosymbiosis; organelles; eukaryote origin; bioenergetics; organelles; physiology; evolution

\begin{abstract}
The origin of eukaryotes is one of the big questions in evolution. Many different ideas about eukaryote origin currently coexist in the literature that weight the evolutionary significance of mitochondria differently. Gradualist theories depict the origin of eukaryotic cell complexity and the origin of mitochondria as independent, unrelated processes that occurred in series. Symbiogenic theories depict the origin of eukaryotic cell complexity as emerging from the symbiosis that gave rise to mitochondria. Since it was introduced over 100 years ago, the idea of symbiogenesis has been controversial. It posits that rarely in Earth history, and only in microbes, a mechanism of evolution has operated in nature that forges new taxa at highest ranks via the endosymbiotic combination of two cells into one. The role of symbiogenesis in evolution versus the gradualist paradigm of constant and incremental mutation accumulation is still debated. A perceived problem with symbiogenesis is that it operates discontinuously and rarely during evolution. Moreover when it does operate, major evolutionary transitions, such as the origin of eukaryotes, plants, and algal groups are the outcome. Here I briefly contrast current symbiogenic and gradualist views on eukaryote origin regarding phagocytosis, the host for mitochondria, eukaryote anaerobes, the eukaryote endomembrane system, gene transfers from organelles, lateral gene transfer, and the number of endosymbiotic partners in eukaryote history. Special attention is given to energy conservation in mitochondria, which fostered eukaryotic complexity by lifting energetic constraints on protein synthesis in mitochondrion bearing cells relative to their prokaryotic ancestors.
\end{abstract}

\section{INTRODUCTION}

The term „symbiogenesis“ made its debut in the literature in the title 1 of Konstantin Mereschkowsky's four parted 1910 series (1), which followed his 1905 exposition that the plastids of plants and algae descend from cyanobacteria via symbiosis (2). The idea of symbiogenesis got off to a rocky start. Mereschkowsky gave the term symbiogenesis (origin via living together) a specific meaning: some higher taxa arise via combination of preexisting cells, one living inside the other. The word placed De Bary's 1878 term symbiosis (3), in Darwin's context of natural variation and cladogenesis. Mereschkowsky pioneered the idea that plants and algae arose symbiogenically, and that eukaryotes arose via symbiogenesis, but he paradoxically rejected the notion that mitochondria were descended from endosymbionts, his symbiogenic origin of eukaryotes has the nucleus being an endosymbiont (1). The symbiogenic origin of mitochondria (but not of eukaryotes) was argued by Portier (4) in French and by Wallin (5) in English, but not, as often claimed, by Altmann $(\sigma)$ in German, who mentions neither 
symbiosis nor mitochondria in his book and whose colonies of 'bioblasts' refer to aggregations (colonies) between organizational states of matter between the level of molecules and cells (bioblasts). Altmann likened his bioblasts to crystals, not to bacteria or to cells. Curiously, Wallin (5) thought that Altmann was talking about mitochondria when he wrote of bioblasts, but having read and reread Altmann $(6)$ neither Höxtermann nor I $(7,8)$ have a clue how Wallin came to that conclusion. Today we know that mitochondria and chloroplasts really did arise via endosymbiosis. We probably know that just as surely as we know that Darwin's basic idea about evolution was correct or that chromosomes are made of DNA. Today people still disagree however whether endosymbiosis was significant as a mechanism of evolution, or whether it just occurred but without evolutionary impact. The debate is not new. Since its inception, the concept of symbiogenesis has polarized biologists and caused debate. Current debate on symbiogenesis has focused on the role of mitochondria at the origin of eukaryotes. Proponents of symbiogenesis, or endosymbiotic theory, have it that symbiosis is a rare but crucial mechanism of evolution $(7,8,9,10,11,12$, 13, 14). Proponents of the opposing gradualist view admit that endosymbiosis occurred when mitochondria arose, but hold that it had no impact on the evolutionary process $(15,16,17)$. Even in 2017, there are staunch opponents of symbiogenesis who argue that mitochondria did not even arise from endosymbionts in the first place (18). Clearly, current views concerning the evolutionary significance of mitochondria in today's literature are divergent.

Diverging views about mitochondrial and eukaryote origin have been summarized in many recent special issues devoted to the topic. The February 2014 special issue of Cold Spring Harbor Perspectives in Biology published a series of reviews on eukaryote origin, as did a 2015 issue of The Philosophical Transactions of the Royal Society of London (vol. 370, no. 1678). A 2015 special issue of The Proceedings of the National Academy of Sciences of the USA (vol. 112, no. 33) published a collection of papers on endosymbiosis and eukaryotes, and in 2017 a special issue of The Journal of Theoretical Biology (still in press at time of submission) was specifically devoted to the topic of endosymbiosis in eukaryote evolution as a summary of what has happened since Lynn Margulis (then under her married name Sagan) published her 1967 paper rekindling and modifying endosymbiotic theory (19). Those special issues underscore broad interest in the question. Other reviews and papers dedicated to the topic have also appeared recently $(10,11,14,20,21,22,23,24)$. Why is so much being written on eukaryote origins? Arguably because the origin of eukaryotes was a very important event in evolution, marking the singular transition in Earth and life history from simply organized cells (prokaryotes) to the complex organized cells (eukaryotes) that make up all complex life. Why yet one more paper? Because we have evidently still not gotten to the heart of the matter.
The main controversy on symbiogenesis concerns eukaryote origin. The debate is not about hopeful monsters (25), saltational evolution (26), or punctuated equilibrium (27), where the conceptual focus gravitates towards the possible evolutionary significance of mutations in one or a few genes that have very large morphological effects. It has more in common with the debate about hybridization in plant speciation, where one rare hybridization event can produce new species with fertile progeny having stark differences in morphology and chromosomes that dwarf, in terms of evolutionary effects per unit time, the workings of standard allele combinations in populations (28). The big difference between hybridization at the origin of new species vs. symbiogenesis at the origin of eukaryotes is that in the former, the partners are interfertile conspecifics or congeners whose progeny have more chromosomes, whereas in the symbiogenic origin of eukaryotes the partners were an archaeon and a bacterium separated by over a billion years of distinct evolutionary history whose progeny have new organelles (mitochondria) and energy metabolism. The debate between gradualism and symbiogenesis at eukaryote origin concerns the nature of evolutionary forces that helped microbes cross the deepest divide in the living world at the level of cell organization: the prokaryote eukaryote boundary.

Serious debates over symbiogenesis have never been about the origin of new species, though Margulis in some of her later writings (29) made wild claims to that effect. From its first appearance in the library over 100 years ago until today, symbiogenesis has been about the origin of two higher taxa of unicellular life forms having novel cell organization relative to their predecessors: eukaryotes and plants (7). This paper is about symbiogenesis at the origin of eukaryotes. Each of the following eight sections briefly highlights diametrically opposed gradualist and symbiogenic views (Table 1) regarding the nature of the evolutionary process underlying the prokaryotic roots (the mitochondrial symbiont and its host) of eukaryotic cells.

\section{Phagocytosis}

Traditional views have it that the host that acquired the mitochondrion obtained it by phagocytosing another cell. In that view, which one might call "phagocytosis first", the cellular machinery required for phagocytosis (uptake of bacterium-sized particles as food) and for gleaning energy from the chemical breakdown of ingested food particles was already present in the host cell that acquired the mitochondrion. In phagocytosis first models, the mitochondrion was the result of a fortuitous meal, the fateful food was not digested and somehow became useful. This view has been around since Margulis (as Sagan) repopularized endosymbiotic theory $(19,30,31,32,33,34,35)$ and has many modern incarnations $(36,37,38,39)$ which envisage the host starting out in evolution organized as a prokaryote, with the evolutionary origin of phagocytosis 
being gradually selected via point mutation and gene duplication before the origin of mitochondria, with phagocytosis being key to acquiring the mitochondrion.

The symbiogenic view posits that the mitochondrion was not acquired by phagocytosis, it entered the host cell by some other mechanism, with phagocytosis arising after the mitochondrion, as reviewed elsewhere (7). Phagocytosis is a feeding habit. For 50 years, people have assumed that phagocytosis was somehow advantageous (35) relative to feeding habits among heterotrophic prokaryotes, which digest their substrates extracellularly and import small molecules. Nobody ever checked to see whether that assumption is true for a prokaryote, until recently (23). We recently did the calculations and found, surprisingly perhaps, that if a prokaryote were to evolve phagocytosis before it acquires mitochondria it would have a much poorer energy yield from substrates than a non-phagocytotic prokaryote (23). That is, ATP yield and energy flux for a hypothetical prokaryote trying to become phagocytic without mitochondria significantly decreases relative to normal prokaryotic heterotrophic energy metabolism, which usually entails chemiosmotic harnessing. This is mainly because a phagocyte cannot maintain chemiosmotic energy conservation in its plasma membrane (23), for which reason a hypothetical prokaryotic phagocyte would have to ingest 34-170 times its weight in 'food bacteria' in order to energetically finance one cell division (23). Phagocytes live from amino acid breakdown, because cells are made mostly out of protein, about $50-60 \%$ by weight, the most common sugar in the cell being ribose, about $8 \%$ by weight ( 40 ). In the presence of mitochondria, a phagocytotic feeding style could be extremely beneficial for the cell, but the energetic prospects for the kind of phagocytosing host for the origin of mitochondria that people have had in mind for 50 years are bleak, at best (23). In other words, if cell already had mitochondria, acquired by any of the phagocytosis-independent mechanisms of symbiotic association that we know among modern prokaryotes (23) such as anaerobic syntrophy (41), then the subsequent origin of phagocytosis could be beneficial (23). Phagocytosis rather clearly appears to be an invention of a cell that had mitochondria, not vice versa (23).

\section{The nature of host that acquired mitochondria}

Related, but not identical, to the proposition that the host for the origin of mitochondria was a phagocyte is the proposition that the host for the origin of mitochondria was a eukaryote, having eukaryotic cell organization, a nucleus, endomembrane system, mitosis, meiosis and so forth, before acquiring the mitochondrion. That view is also about 50 years old $(30,31,32,33,34,35,37,39)$ and is still popular among some specialists (42). It relates to the idea of archezoa $(43,44)$, that is, it entails the existence of primitively amitochondriate eukaryotes, as reviewed elsewhere (45). In essence, the eukaryote host model proposes that eukaryote cell complexity arose before the origin of mitochondria and that - as with phagocytosis first - mitochondria came in after the host had already attained eukaryote cell complexity by standard gradualist mechanisms (mutation, gene duplication, selection).

In symbiogenic models, eukaryotic complexity arose after the origin of mitochondria. Since the late 1970's the archaeal nature of eukaryotic ribosomes $(46,47)$ has been evident, hence the minimalist premise for symbiogenetic models in the modern era (in the times since we knew about archaea) is that the host was an archaeon. Several archaeal host models have been suggested, based on sulfur cycling (48), ATP exchange (49) or $\mathrm{H}_{2}$-based syntrophy (41). Sulfur does play an important role today in mitochondrial metabolism $(50,51,52)$. Clearly, ATP export from the mitochondrion also did come into play at some point in mitochondrial evolution $(49,53,54)$. Yet from the physiological perspective, the proposition of $\mathrm{H}_{2}$-based syntrophy as the initial benefit linking mitochondrion and host (41) is of particular interest because of the widespread occurrence of $\mathrm{H}_{2}$-dependence among modern archaeal lineages that appear related to the host $(55,56)$, the widespread existence of anaerobic syntrophy among modern prokaryotes (57) and especially because of the widespread occurrence of hydrogenosomes and $\mathrm{H}_{2}$-producing mitochondria among eukaryotic anaerobes $(41,58)$.

As current metagenomic studies uncover new archaeal lineages that seem, based on trees of concatenated ribosomal proteins, to be more closely related to the host than cultivated archaeal lineages (24), most observers interpret this as supporting the archaeal host (symbiogenic) concept. That the host should turn out to be an archaeon is precisely the prediction made by some archaeal host models for the origin of mitochondria $(7,41,55,56)$. But in the same breath one should say that concerns have recently come to the fore about the data underlying the phylogenies of the new archaeal lineages (59), in that one of the proteins in the archaeal metagenomic data set might be eukaryotic, not archaeal (59) and might be influencing the phylogenetic signal. It would not be the first time that metagenomic data used for generating concatenated alignments contained small amounts of contaminating signal that could drive the phylogenetic result in a particular direction, as the contrasting results of Rinke et al. (60) and Williams and Embley (61) exemplify. This can happen if the phylogenetic signals of the individual proteins in a concatenated alignment are weak and mildly conflicting (62) in which case one protein with a strong signal out of dozens with weak signals can determine the phylogenetic result in every bootstrap sample of the concatenated data (63). At the same time, the new archaeal lineages that appear to be related to the host are archaea, as archaeal host models predicted (41), and some trees obtain an archaeal host using rRNA sequences alone (20). 


\section{Hydrogenosomes and eukaryotic anaerobes}

As recently explained elsewhere (64), neither Margulis's explicit version of endosymbiotic theory (19) nor less explicit versions descended from it (65) acknowledged the existence of eukaryotic anaerobes. Eukaryotic anaerobes simply did not fit into Margulis's versions of endosymbiotic theory, which were built entirely on oxygen (64). An after the fact remedy to that gap was the archezoa hypothesis, which argued that eukaryotic anaerobes were deep branching lineages that never possessed mitochondria (43). Early trees of rRNA seemed to support that view (66, 67). Two main ideas are currently discussed for the origin of eukaryotic anaerobes, one gradualist, one symbiogenic. The gradualist view is that eukaryotes started out their evolutionary history as obligate aerobes, that the ancestral mitochondrion was an obligate aerobe specialist like Rickettsia (68), and that the ability to survive in anaerobic environments was gradually acquired during evolution in various eukaryotic lineages via lateral gene transfer (LGT), either from prokaryotes or from eukaryotes that had themselves become anaerobic via earlier gradual LGTs $(69,70,71,72,73)$. There are several major problems with the origin of eukaryotic anaerobes via LGT, as discussed at length elsewhere (74), in addition to minor problems, such as the fact that the gradualist LGT origin for eukaryote anaerobes hinges wholly upon Lamarckian inheritance (traits being impressed from the environment into eukaryotic inheritance).

Symbiogenesis has it that eukaryotes started out their evolutionary history as facultative anaerobes that were able to respire oxygen like rat liver mitochondria, but were also able to survive under anaerobic conditions with $\mathrm{H}_{2}$ producing anaerobic fermentations using the oxygen sensitive enzymes germane to hydrogenosomes, anaerobic forms of mitochondria found among all major eukaryotic lineages $(41,58,75)$. In that view, the ancestor of mitochondria was a normal generalist facultative anaerobe, like most modern proteobacteria are $(76,77)$, able to respire oxygen when it was present, but able to switch to anaerobic ATP synthesis and $\mathrm{H}_{2}$-producing fermentations when needed. The symbiogenic view for eukaryote anaerobe origin posits that in addition to the roughly 1000 genes required to make a mitochondrion heritably functional, a dozen or so genes for anaerobic fermentations also entered the eukaryotic lineage at mitochondrial origin, such that aerobic respiration, anaerobic respiration and hydrogen-producing fermentations, in addition to heterotrophy in general, entered the eukaryotic lineage at mitochondrial origin, as a single inheritance from the facultatively anaerobic metabolism of the mitochondrial endosymbiont, followed by ecological specialization differential loss in independent mitochondrion bearing eukaryotic lineages $(41,58)$.

Another important aspect of eukaryotic anaerobes concerns their connections to Earth history. Eukaryotes arose more than 1.5 billion years ago (78), whereby modern views of ocean geochemistry have it that the Earth's oceans were anoxic up until about 580 million years ago (79). That is a major change relative to Margulis's day (19), when it was thought that the oceans became oxic 2.3 billion years ago. That also means that eukaryotes arose and diversified into their major lineages at a time in geological history when anaerobic conditions dominated the Earth's ocean habitats. The gradualist theory that eukaryotes were ancestrally obligate aerobes is not easily integrated into the modern view of Earth ocean chemistry and would require a number of corollaries that its proponents have so far not explicated because they generally make no attempt to integrate the view of anaerobes late into geological accounts of Earth history. The symbiogenic view that eukaryotes were facultative anaerobes from the outset fits very naturally with modern versions of Earth ocean chemistry without additional corollaries $(58,75)$.

\section{The origin of the eukaryotic endomembrane system}

Gradualist depictions have it that the eukaryotic endomembrane system - the endoplasmic reticulum, the Golgi, and its associated vesicle flux - arose from invaginations of the plasma membrane in a prokaryotic cell $(35,42,80,81,82)$. That view is often tightly coupled to the proposition that phagocytosis preceded mitochondria, as outlined in section (I) above, that the host was a eukaryote, as outlined in section (II) above, and with the proposition, usually implicit, that the ER lumen is homologous to the environment surrounding the host that acquired the mitochondrion $(35,42,80,81,82)$.

The symbiogenic version has it that the ancestor of mitochondria, when it took up residence as an endosymbiont in its archaeal host, secreted outer membrane vesicles (OMVs), like modern bacteria do (22). In the symbiogenic context, these OMVs, vesicles of bacterial lipids, accumulated in the archaeal cytosol, providing the seeds of an endomembrane system with ancestrally outward flux upon which the host's archaeal Sec pathway machinery for the insertion of proteins into membranes could operate (22). These vesicles, ancestrally stemming from the mitochondrion, ultimately gave rise to a primitive endomembrane system comprising the ER, from which the nuclear membrane ultimately arose. This would fit with the observation that the nucleus arises from the ER during the cell cycle (83), with the observation that lipid synthesis in eukaryotes is today associated with the mitochondrion and the ER (not with the plasma membrane as in prokaryotes) (22), and with the observation that mitochondria still today actively secrete membrane vesicles into the cytosol (22), they are called mitochondrion derived vesicles, or MDVs (84). Peroxisome biogenesis, long a point of heated debate in the context of eukaryotic endomembrane system origin $(30,85)$, is now increasingly understood as a result of mitochondrial origin $(86,87)$ and was even recently 
shown to require the participation of MDVs $(88,89)$. A physical origin of the eukaryotic endomembrane system from OMVs of the mitochondrial endosymbiont has it that the archaeal lipids of the host were replaced by bacterial lipids through the secretion of bacterial OMVs produced by the mitochondrion, vesicles which today are homologous to MDVs $(22,23)$, and to the proposition that the ER lumen is homologous to the periplasmic space of the mitochondrial symbiont $(22,23)$. This would explain why lipid synthesis in eukaryotes is localized on the mitochondrion and ER while it is localized on the plasma membrane in prokaryotes (22). It would also explain why protein glycosylation occurs at the ER of eukaryotes $(90)$ and at the cytoplasmic membrane of prokaryotes $(91,92)$. In the symbiogenic view, archaeal mechanisms of membrane protein targeting, including the Sec pathway, and dolichol phosphate glycosylation became targeted to cytoplasmic OMVs derived from the mitochondrial endosymbiont, giving rise to a primitive endomembrane system in the nascent eukaryote - an archeaon that harboured a mitochondrial ancestor that secreted vesicles of bacterial lipids into the archaeal cytosol, generating ancestrally outward endomembrane flux (22).

\section{A mechanistic role for mitochondria and their ATP synthesis at eukaryote origin}

For as long as it has been known that mitochondria make ATP via oxidative phosphorylation, it has been clear that ATP production itself cannot have been the initial benefit that associated mitochondria to their host $(41,53)$, which is why other initial benefits of host symbiont association such as $\mathrm{H}_{2}$-production in anaerobic syntrophy have to be considered $(14,41)$. However, it is also clear that the ADP-ATP translocase of the inner mitochondrial membrane was present in the eukaryote common ancestor (93), as was the import machinery of the mitochondrial inner and outer membrane $(94,95)$ that allows mitochondria to import the cytosolic products of genes that it had outsourced to the nucleus (96). From that it follows that in the last eukaryote common ancestor, the mitochondrion was no longer an endosymbiotic bacterium, it had already been converted into an organelle that imported proteins from the cytosol and exported ATP in exchange for ADP before the major eukaryotic lineages has started to diverge.

That is important information to hold onto in thinking about eukaryote origin. The ensuing questions remain simple but the answers are harder. Were mitochondria just an afterthought in the origin of eukaryotes, as the gradualist view would have it? Or did mitochondria actually do something that affected the course of eukaryote origin that would help to explain why the only cells that became eukaryotic derive from an ancestor that possessed mitochondria, as proponents of symbiogenic eukaryote origins contend $(22,23,41,83,97)$.
The recognition that the origin of mitochondria changed the bioenergetic configuration of the eukaryotic cell in such a way as to provide eukaryotes with more energy per gene relative to prokaryotes added impetus to the case for symbiogenesis (54) and helped to underscore the importance of energy in evolution more generally (98). Improved energetics in eukaryotes as a result of mitochondrial origin (the ability of eukaryotes to perform ATP synthesis on internalized bioenergetic organelles as opposed to prokaryotic ATP synthesis at the plasma membrane) goes a long way to explaining why the only cells in nature that are genuinely complex trace to a common ancestor that had mitochondria. Importantly, the energetic difference between prokaryotes and eukaryotes is not oxygen respiration, because facultatively anaerobic but oxygen respiring prokaryotes like $E$. coli never became complex, only the cells that have mitochondria did. The reason is that $\mathrm{O}_{2}$ respiration makes a difference of about 6-fold in ATP yield per glucose - 30 ATP per glucose with $\mathrm{O}_{2}$ vs. 4-5 ATP without $\mathrm{O}_{2}(58)-$ but $\mathrm{O}_{2}$ makes the same difference both in prokaryotes and eukaryotes; by contrast, the presence of mitochondria conferred upon their host several orders of magnitude improvement in terms of energy per gene (54). The connection between energy and complexity is that eukaryotes have additional energy at their disposal for the synthesis of proteins that are not required for core energy metabolic and housekeeping needs, affording them freedom to explore the expression of new proteins, the ones that make the difference between prokaryotes and eukaryotes (54).

The energetic and symbiogenic argument that mitochondria really made a difference at eukaryote origin (54) prompted Booth and Doolittle (15) to argue from a philosophical standpoint that mitochondria had no impact on evolution, to which an exchange $(99,100)$ was published. It also prompted Lynch and Marinov to argue from a population genetic standpoint that mitochondria had no impact on eukaryote evolution and that "variation in the power of random genetic drift has played a central role in the historical diversification of genome and possibly cellular architecture across the tree of life" (16), to which a separate exchange $(101,102)$ was published.

Lynch and Marinov (17) did some more counting in the meantime and concluded once again that "there is no reason to think membrane bioenergetics played a direct, causal role in the transition from prokaryotes to eukaryotes" (17). Lynch has previously argued, independent of energetics, that gradual mutational processes and effective population size, $N_{\mathrm{e}}$, are the sole determinant of the prokaryote to eukaryote transition, hence the papers with Marinov are nothing new. Lynch and Conery (103) stated: "If the theory that we present is correct, and should freeliving prokaryotes with sufficiently small long-term $N_{\mathrm{e}}$ be found, we predict that they will harbor many of the same genomic changes that we have described here for eukaryotes". That view that is reasserted by Lynch and Marinov (17): 
Mitochondria and energy per gene.

1000 Prokaryotic cells

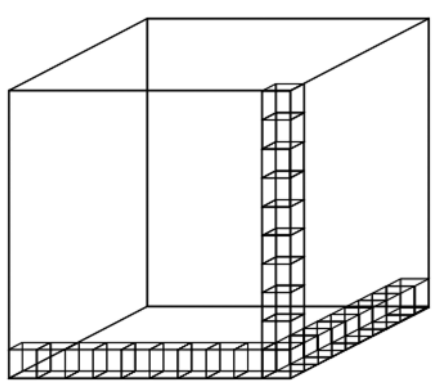

1000 copies of every gene

1000 cell walls, etc...

Each cell has to do it all.

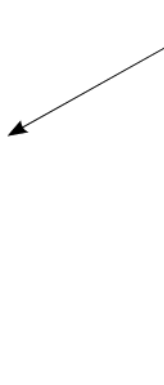

Protein synthesis: $70 \%$ of the ATP budget.

The eukaryotic cell can overexpress protein.

Overexpress what? Enzymes? No. Bad idea.
1 Eukaryotic cell with mitochondria

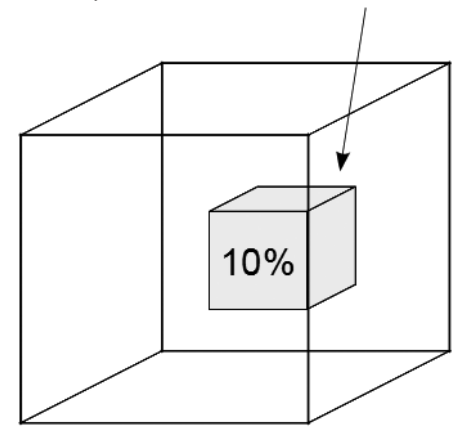

1 copy of every non-mt gene
Human mitochondria operate at $50^{\circ} \mathrm{C}$...

Enzymatically inert proteins that aggregate? Yes.

Figure 1. Schematic depiction of the energetic difference between prokaryotes and eukaryotes. Prokaryotes respire at the plasma membrane, eukaryotes respire in mitochondria. The energetic configuration in eukaryotes has substantial consequences with regard to the energetic capacity of the cell to explore evolutionary tinkering with proteins (see text, see also ref. (54)).

"A plausible scenario is that the full eukaryotic cell plan emerged at least in part by initially nonadaptive processes made possible by a very strong and prolonged population bottleneck". Lynch usually argues that nothing other than nonadaptive processes or $N_{\mathrm{e}}$ impacted any aspect of the evolutionary process, in any organism group (104).

For the sake of those critics $(15,16,17,100,102)$, Figure 1 summarizes once more the bioenergetic difference between prokaryotes and eukaryotes. As summarized from literature values compiled in ref (54), eukaryotes and prokaryotes transduce just as much energy per gram of cells, measured in terms of respiratory rates. No one is debating that. But a gram of prokaryotes contains at least 1000 times more cells than a gram of eukaryotes, if we assume that the prokaryote is about $1 \mu \mathrm{m}$ in diameter and that the eukaryote about $10 \mu \mathrm{m}$ in diameter, whereby eukaryotic cells typically tend to be much larger (17), such that the factor 1000 is conservative. No one is debating that either. That mitochondria comprise about $10 \%$ of the cell volume in a typical heterotrophic eukaryotic cell (105) is also uncontroversial. Thus, in a cell that obtains 2 ATP per glucose from glycolysis and 28 ATP from mitochondrial respiration (106), 10\% of the volume of the cell provides $93 \%$ of the energy. Energy production in eukaryotes is spatially more confined in eukaryotes than it is in prokaryotes. That is because it takes place in mitochondria (eukaryotes), rather than at the plasma membrane (prokaryotes). That spatial confinement is also part of the reason why mammalian mitochondria, for example, operate at about $50^{\circ} \mathrm{C}(107)$. There is a lot of energy flowing through mitochondria.

What is the evolutionary significance of mitochondrial energy? It is this. Eukaryotes and prokaryotes have roughly the same elemental composition (108) and are mostly made of protein, about $50 \%$ by weight $(109,110)$, with protein synthesis accounting for about $75 \%$ of the cell's energy budget (109). Using the same energy per volume, the 1000 prokaryotes (Figure 1 left panel) have to make 1000 cell walls, 1000 genome copies, 1000 cell division machineries and everything else required to make 1000 energy converting self-replicating systems. The eukaryote (Figure 1 left panel) has solved the energy problem with $10 \%$ of the cell volume, and does not need to synthesize 1000 cell walls, 1000 host genomes, 1000 plasma membranes or 1000 lipopolysaccharide layers. The eukaryote has typically one or two non-mitochondrial genome copies, though ribosomal RNA operons are typically amplified in eukaryotes, either as middle repetitive DNA or on plasmids $(111,112,113)$. The function of 1000 genome copies are replaced by mRNA copies stemming from a smaller number of genes. The eukaryote has three orders of magnitude more energy per gene (Figure 1) than the prokaryote (54).

Moreover, the eukaryote does not need to express 1000 times the amount of glycolytic enzymes in order to maintain glycolytic flux, because enzyme levels in cells are al- 
most never rate limiting. Enzymes typically have vast activity reserves to permit regulation and physiological response. A rare exception is $\mathrm{RuBisCO}$, which is a notoriously poor enzyme (114), probably because it arose to do a different job (40), and compensates for poor catalytic rate by comprising about $50 \%$ of leaf protein (115). The eukaryote has solved its carbon and energy problems with $1 / 10^{\text {th }}$ of the cell volume. Relative to the prokaryote, the eukaryote has the same amount of energy per volume in the remaining $90 \%$ of the cell, the cytosol, but with $1 / 1000^{\text {th }}$ the number of transcriptionally active genes. The eukaryote has three orders of magnitude more energy per gene (54) to embark upon the evolutionary tinkering of expressing, overexpressing proteins in the cytosol. It does not have to but thanks to mitochondria it can express cytosolic proteins in large amounts because it has an uncommitted allocation in its energy budget that allows it to do so. That surplus in the eukaryotes energy budget can cover the cost of selectively unconstrained protein expression, an option that the 1000 prokaryotes do not have. In the currency of proteins, a standard currency of cell evolution, tinkering costs energy. The eukaryote can energetically afford to tinker, because mitochondria liberate resources in the cell's energy budget. If evolution works like a tinkerer, evolution with mitochondria works like a corps of engineers (54).

The eukaryote can experiment with overexpressed proteins without sacrificing energy required for other vital functions. It has energy to spare. Because cytosol always ends up being about $400 \mathrm{mg} / \mathrm{ml}$ protein in all cells, that energy can end up being sunk into protein synthesis (where $75 \%$ of the energy in the cell goes anyway). None of the 1000 prokaryotes (Figure 1, left) have the option of tinkering with and overexpressing new proteins to an extent anywhere approaching that in eukaryotes (Figure 1 right), because prokaryotes do not have the energetic benefit of mitochondria.

What can the eukaryote do in an evolutionary sense with novel overexpressed proteins? Improve energy metabolism? Hardly, its energy metabolism is not in need of improvement, it is already off the scale relative to anything that ever lived before it. Overexpress enzymes? Not likely, enzymes when overexpressed tend to interfere with metabolism with detrimental effects for the cells, as most scientists who have ever tried to overexpress enzymes in genetically engineered systems know first hand. Overexpress inert proteins without enzymatic activity? That would appear to be a possible option, at least one that is not immediately deadly, and it is the option that lineage leading to eukaryotes apparently took (116). It is a surprisingly common latent natural property of soluble proteins that they tend to aggregate into linear filaments with only minimal mutational perturbation (117). Eukaryotic cytoskeletal and structural proteins do just that: they spontaneously aggregate in a reversible manner that can be regulated.
In terms of structural cellular complexity, what sets eukaryotes apart from prokaryotes is i) the eukaryotic network of interacting structural proteins in the cytosol, proteins that spontaneously aggregate and undergo active disaggregation at ATP expense and ii) the eukaryotic endomembrane system. From my standpoint (symbiogenesis), it is plainly evident that both pillars of eukaryote cytological complexity - a dynamic proteinaceous cytoskeleton (116) and a dynamic endomembrane system (22) - are properties that emerge from the endosymbiotic origin of mitochondria (23), the former as an energetic consequence, the latter as physical entities. The mitochondrial localization of ATP synthesis permits modern eukaryotes, and permitted the first eukaryotes, to explore the opportunity of protein overexpression that mitochondria afforded, because the intracellular concentration of ATP synthesis in mitochondria provided a cytosol with an increased space and a sufficient energy supply for protein tinkering. My proposition is thus that the mitochondrion arose in a prokaryotic host (41), that the mitochondrial energy configuration permitted that cell to become complex (a eukaryote) $(54,116)$, and that a small population size was conducive to the traversal of that evolutionary transition (118).

Lynch and Marinov's $(16,17,102)$ proposition is that mitochondria are irrelevant to eukaryote origin and that nothing more than point mutations and the power of population bottlenecks are needed to transform a prokaryote into a eukaryote. Such a proposition appears somewhat narrowly focused. If population bottlenecks can make prokaryotes complex, then with all the bottlenecks that prokaryotes underwent in evolution, for example since they started wandering around the land in the guts of land animals over the last 400 million years, we should have seen some bottleneck-generated eukaryote-like complex prokaryotes emerging by now. How many cells might that have been? If we assume a conservative one-week generation time, 400 million years converts to roughly $2 \cdot 10^{11}$ generations. For how many cells? Sender et al. (119) estimate $4 \cdot 10^{13}$ cells per human gut microbiome. If we assume that all land animals, including invertebrates, had a total biomass equal to that of 6 billion humans during the last 400 million years, all with a similar microbiome/bodyweight ratio, we arrive at roughly $5 \cdot 10^{34}$ prokaryotic cells that have constantly been going through prolonged bottlenecks over the last 400 million years. Eukaryote-like prokaryotes have not been reported to be emerging from those gut microbiome bottlenecks yet. And what about the singularity of eukaryotes? Are we to believe that there only was one prokaryotic population size effect during the last 4 billion years that was strong enough to make a prokaryote turn into a mitochondriate eukaryote? Lynch and Marinov $(16,17,102)$ appear, in my view, to be overestimating the power of bottlenecks to create eukaryotes, organelles, or eukaryote like cells.

Though Booth and Doolittle (15) phrase it differently, their message is the same: "We do not actually know, despite 
much theorizing and rhetoric, whether it is luck or skill that has given eukaryotes the advantages that we perceive them to have", and "as likely, we think, is that only one of many neareukaryotic lineages survived. Notwithstanding claims about its enormous evolutionary potential, perhaps that lineage was just lucky!" Their message is that mitochondria made no difference. In a different paper, Doolittle (120) uses the principle of luck to account for the persistence of mitochondria and plastids "Following this logic, it seems that the 'specialness' of organelles comes not from any complex mechanism, or singularity of events, it is just that they are old and have managed not to go extinct. They are the lucky ones." From reading that students might get the impression that chemiosmotic ATP synthesis occurs in mitochondria for no particular reason, it is complete coincidence and it is not only irrelevant for evolution, it could just as easily be taking place in the ER. From my standpoint (physiology), viewing life as an energy releasing chemical reaction and evolution as a process of the maintenance of that exergonic reaction from one generation to the next across nearly 4 billion years (121), the proposition that mitochondria have persisted over 1.5 billion years of eukaryote evolution for no reason other than luck is like saying that vertebrates retained eyes and teeth for 400 million years by pure coincidence, for no evolutionary reason. I find it far more reasonable to think that eukaryotes retained mitochondria and plastids not because of luck, but because they perform the core chemical reactions that run the physiology of the cell (carbon and energy metabolism). In the real world, one cannot replace food and energy with a bit of luck.

Using basic numbers provided by Whitman et al. (122) that roughly $10^{30}$ prokaryotes are alive today, one can estimate that roughly $10^{40}$ prokaryotes have lived on Earth during the last 2 billion years (23), during which time all eukaryotes alive today (the only ones scientists have to account for) arose once. During that same time, the plant lineage arose once. I find that those two transitions are more likely attributable to symbiogenesis (54) than to bottlenecks or luck $(15,16,17)$.

It is undeniable that the advent of plastids corresponds to the origin of all plants we know today, and the advent of mitochondria corresponds to the origin of all eukaryotes we know today. Doolittle and Lynch argue that such correspondence is pure coincidence, that presence of the organelle and the origin of the clade are completely unrelated phenomena, Doolittle adding that the evolutionary persistence of the organelles has no functional basis, it is luck. Their propositions are neither compelling, nor do they make physiological sense. This section was long because I find it important to underscore how fundamentally different gradualist and symbiogenic views are on the role of mitochondria at eukaryote origin. In contrast to gradualist claims, there are well-founded biochemical and physiological reasons to think that mitochondria played an energetic role at eukaryote origin.

\section{Gene transfers from organelles}

Small population sizes allow mutations to become fixed more rapidly than in large populations (123). But it is mutation, not $N_{\mathrm{e}}$, that provides the substance with which evolution produces change (123). No mutation, no evolution, regardless of population size. Gene transfers from endosymbiotic organelles to their host are a mechanism of mutation that is both specific to symbiogenesis and specific to the eukaryotic lineage $(124,125,126)$. Eukaryotes are genetic chimaeras, with more bacterial genes than archaeal genes $(127,128,129,130)$, and gene transfers from mitochondria and chloroplasts continue to permeate eukaryotic chromosomes via known mechanisms - non homologous end joining (126) - that can be observed in the laboratory (131). Gene transfers from the mitochondrial symbiont to host chromosomes were important at eukaryote origin (41). Given what we have learned about the abundance of plastid and mitochondrial DNA in eukaryotic genome sequences $(124,125,126,132,133)$, that set of propositions would seem far less controversial than it did 20 years ago, one would think.

Proponents of the gradualist case now even challenge the idea that gene transfers from organelles to the nucleus took place. One recent suggestion by Keeling and McCutcheon has it that maybe there really weren't any transfers from organelles after all (134). They make that case by extrapolating from bacterial endosymbionts of insects under the highly questionable premise, which they do not articulate, that such symbioses (between bacteria and insects) serve as a relevant biological model that might shed light on symbioses between bacteria and archaea that occurred at the origin of mitochondria. Insects are not archaea. The endosymbionts of insects are exceedingly common and the symbiotic associations occur recurrently in individual insect lineages (135), which is in stark contrast to the singular origin of plastids in the plant lineage or the singular origin of mitochondria. In arguing the case that gene transfers from organelles might not occur, Keeling and $\mathrm{McCutcheon}$ overlook repeatedly and independently confirmed evidence that nuclear fragments of mtDNA really do permeate all genomes of eukaryotes that possess DNA in their mitochondria, that humans are polymorphic for mtDNA insertions at 141 loci and that at least five mtDNA insertions cause human disease (133). We can see clear and concrete evidence for the workings of gene transfers from organelles today. The principle of continuity would have it that such transfers were taking place in the past as well.

Clearly, there is diversity of views regarding gene transfers from mitochondria and chloroplasts, and diversity of views is not uncommon in the field of evolutionary biology. At any rate, the $580 \mathrm{~kb}$ of recently acquired mitochondrial DNA in our own human nuclear genome (126, 133) in addition to the complete $660 \mathrm{~kb}$ mitochondrial genome on chromosome 2 of Arabidopsis and the $130 \mathrm{~kb}$ complete plastid genome on chromosome 10 of rice (136) 
are best explained by accepting the proposition that gene transfers from mitochondria and plastids to the nucleus really do occur during evolution (137).

\section{Gradual lateral gene transfer vs. gene transfers from organelles}

The role of lateral gene transfer in eukaryote evolution has been more thoroughly addressed elsewhere (74). In brief, most claims for eukaryote LGT are probably untrue (74). Here it is only important to stress that there are gradualist and symbiogenetic views on $L G T$ as it specifcally relates to eukaryote origin. The gradualist view has it that gene transfer between prokaryotes and eukaryotes is just as common in evolution as gene transfer among prokaryotes $(138,139,140)$. Specific formulations of LGT at eukaryote origin even have it that gradual LGT into the eukaryotic lineage is what made eukaryotes eukaryotic (141). Indeed, Pittis and Gabaldon (141) are saying that eukaryotes gradually acquired, from prokaryotes, the genes that make eukaryotes eukaryotic, deriving a mitochondrion lacking eukaryote (an archezoon) that acquires the mitochondrion to terminate the process of eukaryogenesis.

There are three very fundamental flaws with the gradualist LGT suggestion of Pittis and Gabaldon (141) and its content. First, its conclusions derive entirely from multiple and severe data analysis artefacts (142). Second, the paper suggests that the stem eukaryotic lineage acquired from prokaryotes the genes for the traits that make eukaryotes eukaryotic (a fully fledged endomembrane system, vesicle flux, nucleus, a true cytoskeleton, cell cycle, mitosis, meiosis, syngamy, karyogamy, sex, alternation of generations, etc.), but prokaryotes do not have those traits, only eukaryotes do $(23,116,143)$. How can eukaryotes acquire genes from donors that lack the traits to be acquired? Third, the popularity of eukaryote LGT $(69,70,71,72$, $140,144,145$ ) should not obscure the fact that it is Lamarckian in tooth and claw. Eukaryote LGT proponents are saying that the genes required for survival in anaerobic environments (72), or the genes required for the origin of eukaryote complexity (141) are first acquired from outside the eukaryotic lineage, then inherited within eukaryotes to fulfill some purpose, for example adaptation to anaerobic environments or origins of complexity. How are such views not Lamarckian, and does anybody notice or care? Should we teach our students that eukaryotes, including animals (146), evolve in a Lamarckian manner? There is something fundamentally wrong with eukaryote LGT claims (74).

At the other end of the spectrum is the symbiogenic proposition that eukaryotes do not acquire genes via outright LGT either from other eukaryotes or from prokaryotes except at endosymbiotic events (the origin of mitochondria, the origin of primary plastids, the origin of secondary plastids) $(21,83,130,147)$. We can see cumulative effects of LGT in prokaryotic genomes (148). We can also see evidence for mass transfers in prokaryotic genomes $(149,150)$. But when we look for cumulative effects of LGT in eukaryotes, there is no evidence to be found $(21,147)$. What do I even mean by cumulative effects? Cumulative effects are Darwinian effects. If changes occur over time along a lineage, they accumulate, and cumulative effects become visible. Darwin saw that for morphology. The Modern Synthesis saw it for mutations. Since Dayhoff's day (151) we see it in proteins as accumulated substitutions alias sequence divergence. LGT has clear cumulative effects in prokaryotes (148) but not in eukaryotes $(21,147)$. The symbiogenic version of eukaryote gene transfer is that eukaryotes acquired genes at the origins of mitochondria and chloroplasts and with the help of that genetic starting material plus its ensuing mutations (and mitochondrial energy), selection and differential loss set in to allow eukaryotes to evolve in a very normal Darwinian manner, at least one they had evolved meiosis (110), without the inheritance of acquired traits.

\section{Gradualist versions of symbiogenesis}

There are also gradualist versions of symbiogenesis. Gradualistic symbiogenesis - how can that be, one might ask. Ideas about the role of symbiogenesis can be distributed along a scale from zero to one, as sketched in Figure 2. At the one extreme is the pure gradualist view that symbiogenesis had no role at all in eukaryote origin, that eukaryotes arose without the participation of symbiogenesis or mitochondria. There are versions of nonsymbiogenic eukaryote origins starting from archaea (47) (Fig. 2a) and versions starting from bacteria (35) (Fig. 2b), models in which mitochondria are added to a eukaryotic cell that arose gradually. More modern versions of nonsymbiogenic eukaryote origins tend to focus on gradualist mechanisms while largely disregarding the issue of „origin from which kinds of prokaryote" $(15,16,17,102,120)$. By contrast, older gradualist hypotheses of Van Valen and Maiorana (47) and Cavalier-Smith (35) are more courageously explicit on phylogenetic relationships.

At the other extreme is the undiluted version of symbiogenesis (Fig. 2f), namely that the host for the origin of mitochondria was a prokaryote, an archaeon, and that eukaryote specific traits arose as a consequence of that symbiosis $(22,23,41,54,118)$. There are several versions of the idea that the host was an archaeon (reviewed in (45, $51)$ ), though only one of those suggestions accounted for eukaryotic anaerobes (41), having been developed into a fuller theory that makes an earnest attempt to account for the origin of the nucleus (7), the eukaryotic endomembrane system (22), meiosis mitosis and sex (116).

In the middle of the autogeny-symbiogenesis scale are very many published versions of symbiogenesis that posit the participation of additional symbioses that took place before the origin of mitochondria in the process of eu- 
No symbiogenesis

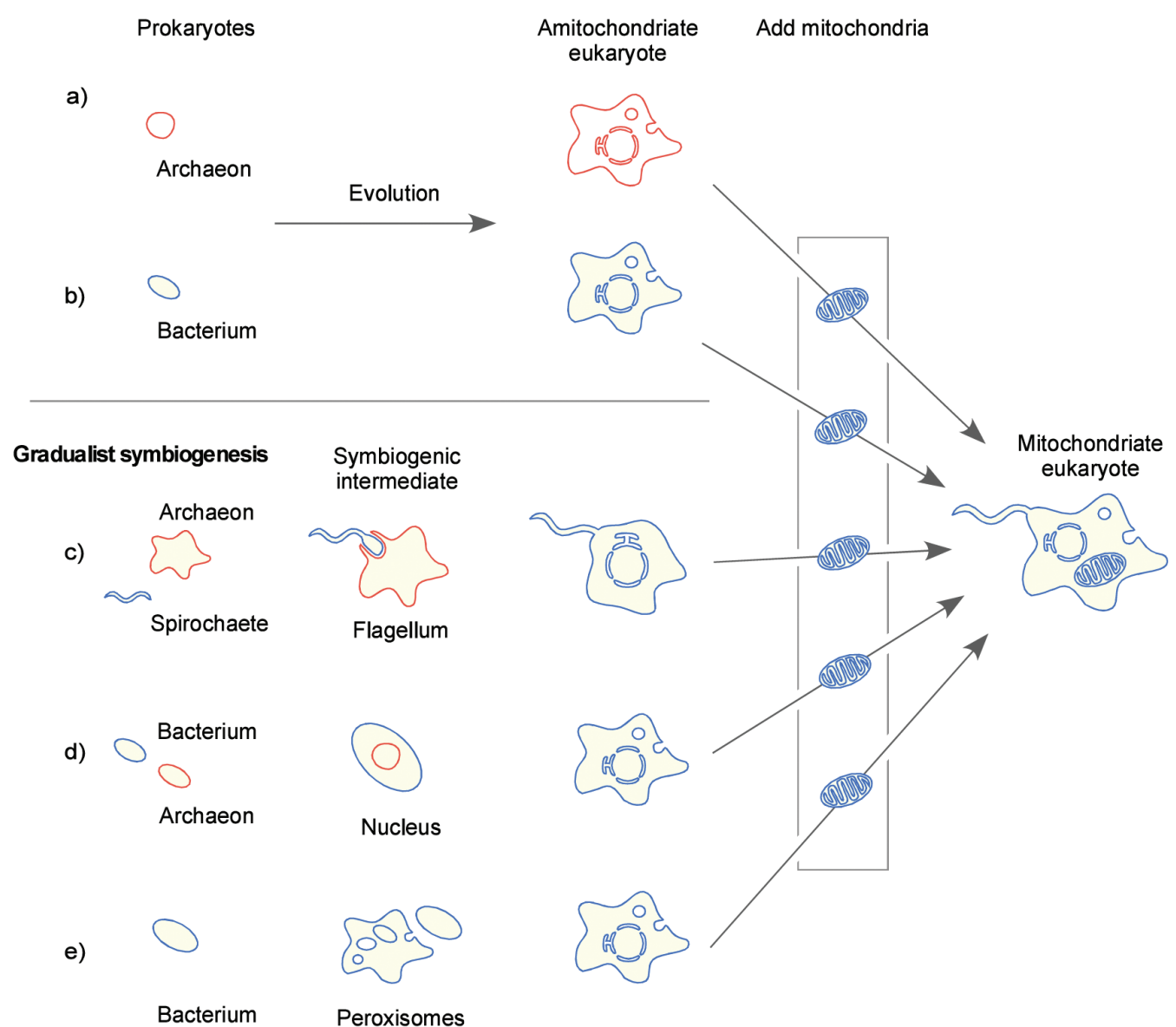

\section{Symbiogenesis}

f)

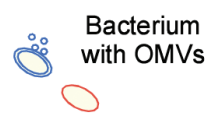

Archaeon
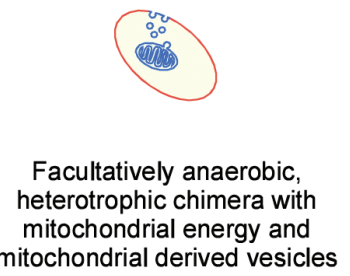

acultatively anaerobic,

mitochondrial energy and mitochondrial derived vesicles

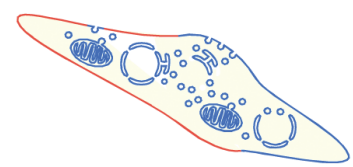

Chimaeric, symbiogenic cell (probably syncytial) with mitochondrial derived endomembrane system

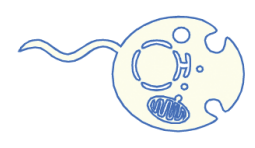

Facultatively anaerobic mitochondrite eukaryote

Figure 2. Schematic comparison of selected theories for eukaryote origin. For a more complete overview see (7). In the top panel, two autogenous models are shown. a) Origin from an archaeon (47), b) origin from a bacterium (35), mitochondria coming later. In the middle panel, three gradualist symbiogenic models are shown in which a symbiosis takes place to generate a primitively amitochondriate eukaryote (an archezoon), which then acquires mitochondria. c) An amitochondriate eukaryote arises via a symbiosis involving a spirochaete (159). d) An amitochondriate eukaryote arises via a symbiosis involving the origin of the nucleus $(152,153)$. e) An amitochondriate eukaryote arises via a symbiosis involving the origin of peroxisomes $(30,85,154)$. f) A eukaryote having mitochondria, a nucleus, an endomembrane system, meiosis, and sex arises from a symbiotic association of an archeaon (the host) and a bacterium (the common ancestor of mitochondria and hydrogenosomes) without additional symbiotic partners $(7,10,22,23,41,54,55,58,116)$. In $f)$ a syncytial intermediate is sketched, because such an intermediate would decouple the origin of nuclear division, chromosome partitioning onto progeny and cell division, which would help to account for the origin of sex and meiosis in the eukaryote ancestor (see text, see also ref. (116)).

karyogenesis. These additional symbioses give rise to a cell that does not have mitochondria but is more complex than a prokaryote. There are many such suggestions in the lit- erature (reviewed in (7)). The best known examples are the idea that an additional symbiont gave rise to the flagellum (Fig 2c) (19), the idea that the nucleus was an endo- 
symbiont (Fig. 2d) $(152,153)$ and the idea that peroxisomes were endosymbiotic bacteria (Fig. 2e) $(30,85,154)$. What gradualist versions of symbiogenesis do is simple, but incorrect in my view: They take the principle of endosymbiosis, which we know to be correct for plastids and mitochondria, and they apply it once more to cell evolution in order to make the host for mitochondrial origin more complex than a simple prokaryote. They make the symbiogenic origin of eukaryotes more gradual. They tend to associate the additional symbiosis with the origin of a particular cell structure (flagellum, nucleus, peroxisome), giving rise to a eukaryotic like cell that lacks mitochondria, then they add the mitochondrion. Curiously, I have never come across a paper where someone suggests endosymbiosis for the origin of flagellum, and for the nucleus, and for peroxisomes (or any combination of thereof). It is always either one endosymbiosis preceding the mitochondrion, or none. Taylor (80) called such successive symbioses serial endosymbiotic theory, or SET, a term I have never used because the serial part of it (Margulis's spirochaete flagellae) has always been obviously flawed (64), while the mitochondrial and plastid part has been undeniable. Perhaps there is something about the principle of symbiogenesis (endosymbiosis) that tells biologists to use it sparingly. One can entertain more than two prokaryotic endosymbionts in eukaryote evolution (mitochondria and plastids), but not fewer.

There is also a gradualist symbiogenic version for the origin of plastids. That idea involves a chlamydial symbiont that helped the cyanobacterium become a plastid. The "chlamydioplast" notion was construed entirely from genome data; for a critical review of the idea explaining its a flaws in context, see (155). Importantly, the phylogenies that are claimed as support for the chlamydia story do not support it at all $(155,156)$.

The minimalist and most radical version of symbiogenesis is this: i) A symbiosis between an archaeal host and a bacterial endosymbiont gave rise to a mitochondrion and nucleus bearing cell, the first eukaryote (41), which was probably syncytial as meiosis was arising (116) and from which all eukaryotes descend (Figure 2). ii) One more symbiogenic association gave rise to the first cell with plastids $(7,9,10,11)$, from which all plants (now called ar- chaeplastida) descend. iii) Secondary symbioses occurred among eukaryotes to give rise to algae with secondary plastids (83). That assumes the rock bottom minimum number of symbioses at the origin for groups whose cell biology harbours unequivocal evidence in the form of bioenergetic organelles - mitochondria, primary plastids and secondary plastids - that symbioses occurred. It does not assume, entail or require the existence of any additional endosymbionts for which there is no evidence in the currency of organelles. Gradualist versions of symbiogenesis strive to make the steps at the origin of eukaryotes less steep by adding additional symbiotic partners (Fig 2c-e) to create intermediate forms unknown among modern cells. In Fig 2f, the bottom panel, one can add additional symbionts that do not give rise to a eukaryote with mitochondria, but one cannot get by with fewer. That is, symbiogenic models can only get more complicated, they cannot get simpler. I see that as a strength of the theory.

\section{WHY ALL THE CONTROVERSY, WHAT IS THE PROBLEM?}

On the bottom line, the gradualist and symbiogenic theories differ over a simple but profound question: Did mitochondria terminate the process of eukaryogenesis as gradualists say, or did mitochondria initiate the process of eukaryogenesis, as symbiogenesis would have it (Table 1). Many observers will no doubt opt for a compromise solution and say "Well, the answer is somewhere in between". The literature has plenty of compromise solutions in supply. One compromise solution involves archezoa or "phagocytosing archaea" as intermediates in the prokaryote eukaryote transition $(39,157)$. The problem with the notion of phagocytosing archaea is that the idea will not work, for physiological and energetic reasons (23). Another compromise solution involves gradualist versions of symbiogenesis that conjure additional symbionts to make the host for the origin of mitochondria more complex than a prokaryote (Figure $2 \mathrm{c}-\mathrm{e}$ ). There are two main problems with such additional symbiont theories. First, they derive an archezoon, usually a phagocytosing one, as the host for mitochondria (Figure $2 \mathrm{c}-\mathrm{e}$ ), which does not work for many reasons $(7,23,45)$. Second they have been specifically tested with extensive genome sequence data with the

Table 1. Differing views about eukaryote origin

\begin{tabular}{|lll|}
\hline Aspect & Gradualist view & Symbiogenic view \\
\hline 1. Phagocytosis & Arose before mitochondria & Arose after mitochondria \\
2. The host for mitochondria & Was a eukaryote & Was a prokaryote (an archaeon) \\
3. Eukaryote anaerobes & Arose late through LGT & Facultatively anaerobic ancestral state \\
4. Endomembrane system & Arose before mitochondria & Arose from mitochondrial vesicles \\
5. Mitochondrial ATP synthesis & Irrelevant, of no significance & Permits increased protein expression \\
6. Gene transfers from organelles & Not frequent, not important & Frequent, important, transformative \\
7. LGT to and among eukaryotes & A mechanism of evolution & Lamarckian artefact of data analysis \\
8. Endosymbiotic partners & Host, mitochondrion, plus others & Host and mitochondrion only \\
9. The role of mitochondria & Terminated eukaryote origin & Initiated eukaryote origin \\
\hline
\end{tabular}




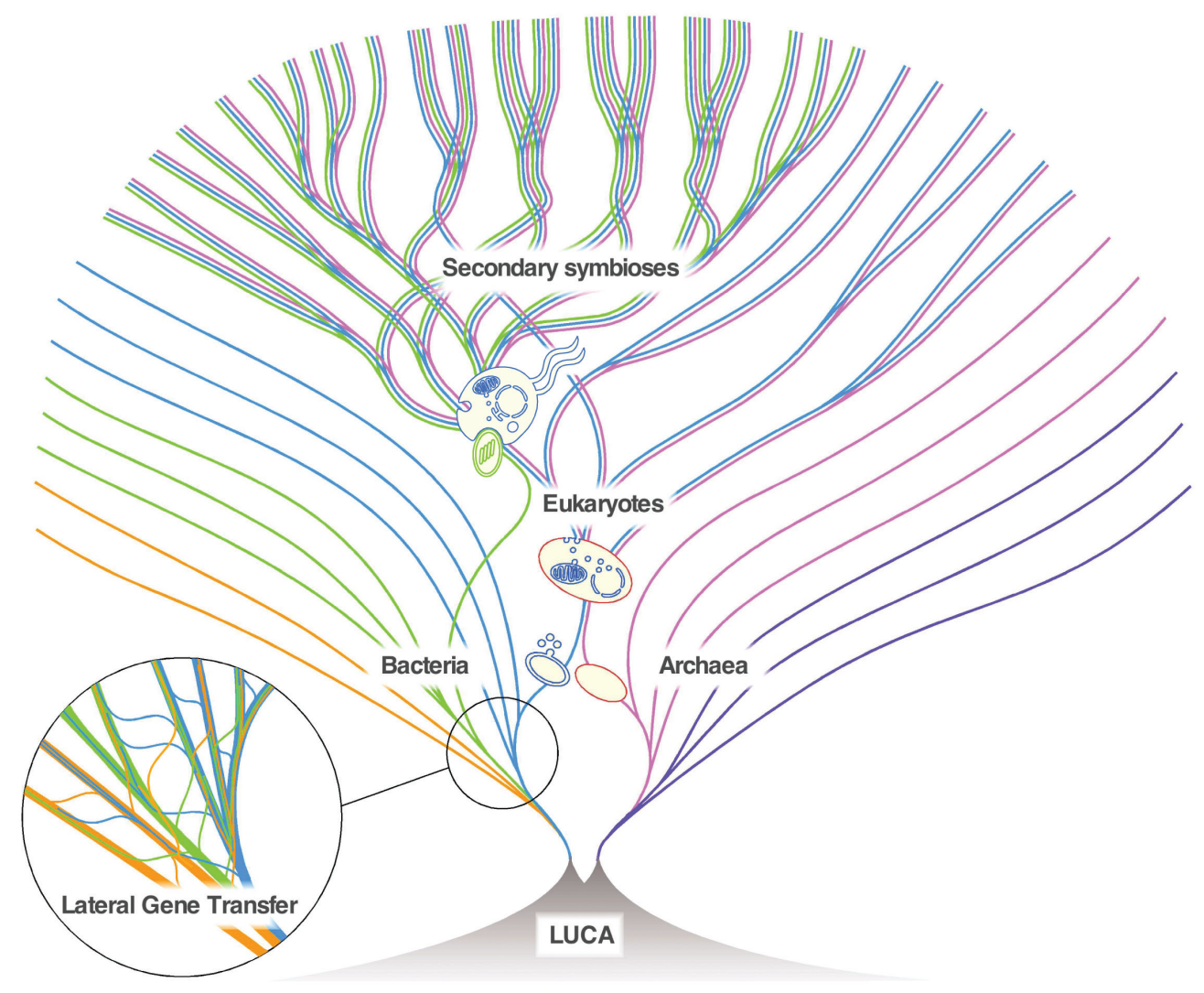

Figure 3. Symbiogenesis in eukaryote evolution. The figure is slightly modified from reference (162). The symbiogenic origin of eukaryotes (mitochondria), plants (plastids) and lineages with secondary plastids is shown. For further details see (7, 10, 22, 23). In the figure, four independent secondary symbiotic events are depicted, one each leading to euglenids and chlorarachniophytes (both green algal symbionts) and two more involving red algal endosymbionts, although at present, information about protein targeting into secondary plastids suggests that only one secondary symbiosis involving a red algal symbiont took place, for further details see (163). LUCA designates the last universal common ancestor of all cells, see reference (164).

sobering result that genomes harbour no evidence for such ideas (21). Yet another compromise solution is to draw pictures of eukaryogenesis as involving extra symbiotic partners in addition to the mitochondrion and the host, but without specifying what those symbiotic partners are or what they were doing in a physiological sense (158). Such propostions are untestable.

Tests are an issue with which endosymbiotic theory traditionally has had a problem. Margulis held on to her spirochaete origin of flagella for 40 years (159) despite the idea failing all molecular tests. The kind of evidence that virtually all scientists accepted as supporting the idea that plastids and mitochondria are descended from endosymbionts, namely molecular sequence comparisons and molecular evolution (160), rejects the idea that endosymbionts other than the plastid and the mitochondrion participated in eukaryote evolution (21). Some scientists reject the idea the mitochondria were endosymbionts at all (18). Others argue that the role of symbiosis in the origin of new species of termites or lichens constitutes a test of the idea that mitochondria played a role at eukaryote origin (161). Margulis (29) made exactly the same mistake by trying to sell symbiogenesis as a replacement for gradualist evolutionary mechanisms as opposed to incorporating it into the broader fabric of evolutionary biology as a rare (extremely rare, but indispensable) exception to the gradualist rule. As I see it, the central problem surrounding acceptance of symbiogenic mechanisms is that they only operate very rarely in evolution. That makes them interesting, but controversial, as summarized in Figure 3.

Current views on the role of symbiogenesis in evolution diverge to extremes. Physicists and chemist find such dissent unfathomable. Why is biology so different? Maybe it is simple: Everyone agrees that the laws governing physical and chemical processes have been constant over the last 4 billion years. The same level of agreement does not exist in biology, specifically in evolution, where scientists are still vigorously debating whether gradualist mechanisms will suffice to account for all of evolutionary history. Here I have made a case that symbiogenesis is not only required to explain the origin of cells with mitochondria and plastids during the last 4 billion years, but it actually does a better job than gradualist mechanisms at the origin of eukaryotes and plants. Alas, gradualists will not change their views on 
the nature of mechanisms that operated in early evolution. That's fine. But why do biologists not agree on such fundamental issues, how can such divergent interpretations of the same body of literature coexist? A main factor is that symbiogenesis pertains to the study of early evolution.

I have observed that scientists (n.b.) tend to make up their mind very early in their careers about the course of early evolution - that is, the origin of life and the origin of eukaryotes - , not seldom by absorbing and clinging to the first halfway convincing thing they ever heard or read on the topic. We have a tendency to hang onto those initial views regardless of what comes along over the years in terms of new evidence, because that initially imprinted view of early evolution is somehow incorporated into the fabric of our thinking as a kind of internal scaffold. As our careers progress, we attach new information onto that scaffold while we construct our own private view of life history. To be sure, there is nothing wrong with that, moreover I consider that to be a non-negotiable component of our scientific freedom, or a God given right, as one would prefer to express it.

We hang new observations or new information from the literature on that scaffold as we move forward through our careers, constructing our own increasingly detailed, private narrative about life history in the process. If new information comes along that conflicts with our private narrative, our tendency is to dismiss it, ignore it, hope that it will somehow go away, or inspect the robustness of the new information rather than modify the scaffold. Such inertia is not entirely bad, because the literature on early evolution is very diverse, and we are certainly ill-advised to believe everything we read, in which case the scaffold would collapse in conflict. On the contrary, we need to be critical and stay critical in the face of the many strange claims that constantly appear in the literature about early evolutionary history. Modifying our scaffold entails time, effort, and internal conflict (decisions) as we rebuild and reconstruct our private life history narrative. We cannot incorporate and reconcile all views that are out there, anyway, because they conflict in basic substance. We have to select. But we do have to update and modify our scaffold from time to time, otherwise it is not part of science. That is too much effort for most of us, especially if early evolution is not our main research focus. In essence, no amount of data will cause some of us to change our minds about early evolution. That is certainly understandable, though not always compatible with of the scientific process. Many heated debates about early evolution are argued from the fabric of our inner scaffolds and hence end without agreement. Scientists who do not care about early evolution do not debate it.

Be that as it may, taxpayers expect scientists to adjust their views on early evolution as new information becomes available. The difference between science and religion is that in religion the truth stays the same over millennia while in science the truth (our premises, the things we be- lieve to be true for the sake of scientific inquiry) is supposed to change over time. It is called progress. Ideally we are supposed to be able to see views progress during our own lifetime. That is the nature of what we do. In evolution there are no facts, there are only observations and their interpretation. That is what makes it such a rich and exciting field.

\section{CONCLUSION}

The term symbiogenesis entered the literature at a time when Spiridion Brusina (1845-1909) was still active (165). He founded the learned academic society that publishes this distinguished journal, which has been continuously in print since 1886 . Brusina was a prominent biologist and leading malacologist of his day. The title of his 1904 contribution (165) translates to „On saving our molluscan fauna“. Today we would think that a paper with such a title would be about saving endangered species. Brusina was not warning that the species themselves were endangered. Rather he was explaining how his unfinished monographs on the species of European molluscs were becoming endangered because of administrative duties, because of competitors at better funded institutions, and because of the tedious burden of having to straighten out a complete mess in the literature that had arisen through very problematic recent publications that were impeding his work and holding back progress in general. Brusina was ahead of his time, he was also right: European molluscs harbour fascinating biology. Some molluscs even sequester plastids from algae, for reasons relating to feeding physiology, however (166), not symbiogenesis. Were Spiridion Brusina still alive today, it is my hope that he would have enjoyed this paper.

Acknowledgements: I thank Sven Gould, Sriram Garg, Verena Zimorski and all members of the Institute for Molecular Evolution for discussions, the ERC (grant 666053) and the Volkswagen foundation (Life) for financial support, Verena Zimorski for help in preparing the manuscript, and the Croatian Society of Natural Sciences for the invitation to submit this paper.

\section{REFERENCES}

1. MERESCHKOWSKY C 1910 Theorie der zwei Plasmaarten als Grundlage der Symbiogenesis, einer neuen Lehre von der Entstehung der Organismen. (Theory of two plasma types as the basis of symbiogenesis, a new theory of the origin of the organisms.) Biol Centralbl 30: 278-288, 289-303, 321-347, 353-367 [German]

2. MERESCHKOWSKY C 1905 Über Natur und Ursprung der Chromatophoren im Pflanzenreiche. (On the nature and origin of chromatophores (plastids) in the plant kingdom.) Biol Centralbl 25: 593-604 [German] (English translation in: MARTIN W, KOWALLIK K 1999 Annotated English translation of Mereschkowsky's 1905 paper. Eur J Phycol 34: 287-295; https://doi.org/10.1080/09670269910001736342

3. DE BARY A 1878 Über Symbiose. (About symbiosis.) Tageblatt der 51. Versammlung deutscher Naturforscher und Aerzte in Cassel, 121-126 [German] 
4. PORTIER P 1918 Les symbiotes. (The symbionts.) Masson, Paris [French]

5. WALLIN IE 1925 On the nature of mitochondria. IX. Demonstration of the bacterial nature of mitochondria. Am J Anat 36: 131139 https://doi.org/10.1002/aja.1000360106

6. ALTMANN R 1890 Die Elementarorganismen und ihre Beziehungen zu den Zellen. (The elementary organisms and their relationship to the cells.) Verlag von Veit \& Comp., Leipzig, p 145 [German]

7. MARTIN W, GARG S, ZIMORSKI V 2015 Endosymbiotic theories for eukaryote origin. Philos Trans R Soc Lond B 370: 20140330 https://doi.org/10.1098/rstb.2014.0330

8. HÖXTERMANN E, MOLLENHAUER D 2007 Symbiose und Symbiogenese - Entdeckung und Entwicklung eines biologischen Problems. (Symbiosis and symbiogenesis - Discovery and development of a biological problem.) In: Geus A, Höxtermann E (eds) Evolution durch Kooperation und Integration. (Evolution through cooperation and integration.) Basilisken-Presse, Marburg an der Lahn, p 258 [German]

9. ALLEN JF 2015 Why chloroplasts and mitochondria retain their own genomes and genetic systems: Colocation for redox regulation of gene expression. Proc Natl Acad Sci U S A 112: 10231-10238 https://doi.org/10.1073/pnas.1500012112

10. ZIMORSKI V, KU C, MARTIN WF, GOULD SB 2014 Endosymbiotic theory for organelle origins. Curr Opin Microbiol 22: 38-48 https://doi.org/10.1016/j.mib.2014.09.008

11. ARCHIBALD JM 2015 Endosymbiosis and eukaryotic cell evolution. Curr Biol 25: R911-R921 https://doi.org/10.1016/j.cub.2015.07.055

12. MCINERNEY JO, O'CONNELL M, PISANI D 2014 The hybrid nature of the Eukaryota and a consilient view of life on Earth. Nat Rev Microbiol 12: 449-455 https://doi.org/10.1038/nrmicro3271

13. LANE $N 2017$ Serial endosymbiosis or singular event at the origin of eukaryotes? J Theor Biol 434: 57-67 https://doi.org/10.1016/j.jtbi.2017.04.031

14. ZACHAR I, SZATHMÁRY E 2017 Breath-giving cooperation: Critical review of origin of mitochondria hypotheses - Major unanswered questions point to the importance of early ecology. Biol Direct 12: 19 https://doi.org/10.1186/s13062-017-0190-5

15. BOOTH A, DOOLITTLE WF 2015 Eukaryogenesis, how special really? Proc Natl Acad Sci U S A 112: 10278-10285 https://doi.org/10.1073/pnas.1421376112

16. LYNCH M, MARINOV GK 2015 The bioenergetic costs of a gene. Proc Natl Acad Sci U S A 112: 15690-15695 https://doi.org/10.1073/pnas.1514974112

17. LYNCH M, MARINOV GK 2017 Membranes, energetics, and evolution across the prokaryote-eukaryote divide. Elife 6: e20437 https://doi.org/10.7554/eLife.20437

18. HARISH A, KURLAND CG 2017 Mitochondria are not captive bacteria. J Theor Biol 434: 88-98 https://doi.org/10.1016/j.jtbi.2017.07.011

19. SAGAN L 1967 On the origin of mitosing cells. J Theoret Biol 14: 225-274 https://doi.org/10.1016/0022-5193(67)90079-3

20. WILLIAMS TA, FOSTER PG, COX CJ, EMBLEY TM 2013 An archaeal origin of eukaryotes supports only two primary domains of life. Nature 504: 231-236 https://doi.org/10.1038/nature12779

21. KU C, NELSON-SATHI S, ROETTGER M, SOUSA FL, LOCKHART PJ, BRYANT D, HAZKANI-COVO E, MCINERNEY JO, LANDAN G, MARTIN WF 2015 Endosymbiotic origin and differential loss of eukaryotic genes. Nature 524: 427432 https://doi.org/10.1038/nature14963

22. GOULD SB, GARG SG, MARTIN WF 2016 Bacterial vesicle secretion and the evolutionary origin of the eukaryotic endomembrane system. Trends Microbiol 24: 525-534 https://doi.org/10.1016/j.tim.2016.03.005

23. MARTIN WF, TIELENS AGM, MENTEL M, GARG SG, GOULD SB 2017 The physiology of phagocytosis in the context of mitochondrial origin. Microbiol Mol Biol Rev 81: e00008e00017 https://doi.org/10.1128/MMBR.00008-17

24. ZAREMBA-NIEDZWIEDZKA K, CACERES EF, SAW JH, BÄCKSTRÖM D, JUZOKAITE L, VANCAESTER E, SEITZ KW, ANANTHARAMAN K, STARNAWSKI P, KJELDSEN KU, STOTT MB, NUNOURA T, BANFIELD JF, SCHRAMM A, BAKER BJ, SPANG A, ETTEMA TJG 2017 Asgard archaea illuminate the origin of eukaryotic cellular complexity. Nature 541: 353-358 https://doi.org/10.1038/nature21031

25. THEISSEN G 2006 The proper place of hopeful monsters in evolutionary biology. Theory Biosci 124: 349-369 https://doi.org/10.1016/j.thbio.2005.11.002

26. THEISSEN G 2009 Saltational evolution: Hopeful monsters are here to stay. Theory Biosci 128: 43-51 https://doi.org/10.1007/s12064-009-0058-z

27. GOULD SJ, ELDREGE N 1993 Punctuated equilibrium comes of age. Nature 366: 223-227 https://doi.org/10.1038/366223a0

28. RIESEBERG LH 1997 Hybrid origins of plant species. Annu Rev Ecol 28: 359-389 https://doi.org/10.1146/annurev.ecolsys.28.1.359

29. MARGULIS L, SAGAN D 2002 Acquiring Genomes: A Theory for the Origins of Species. Basic Books, New York.

30. DE DUVE C 1969 Evolution of the peroxisome. Ann N Y Acad Sci 168: 369-381 https://doi.org/10.1111/j.1749-6632.1969.tb43124.x

31. STANIER Y 1970 Some aspects of the biology of cells and their possible evolutionary significance. Symp Soc Gen Microbiol 20: $1-38$

32. DOOLITTLE WF 1998 You are what you eat: A gene transfer ratchet could account for bacterial genes in eukaryotic nuclear genomes. Trends Genet 14: 307-311 https://doi.org/10.1016/S0168-9525(98)01494-2

33. ROGER AJ 1999 Reconstructing early events in eukaryotic evolution. Am Nat 154: S146-S163 https://doi.org/10.1086/303290

34. CAVALIER-SMITH T 1987 The origin of eukaryote and archaebacterial cells. Ann N Y Acad Sci 503: 7-54 https://doi.org/10.1111/j.1749-6632.1987.tb40596.x

35. CAVALIER-SMITH T 2002 The phagotrophic origin of eukaryotes and phylogenetic classification of protozoa. Int J Syst Evol Microbiol 52: 297-354

https://doi.org/10.1099/00207713-52-2-297

36. FIELD MC, SALI A, ROUT MP 2011 On a bender-BARs, ESCRTs, COPs, and finally getting your coat. J Cell Biol 193: 963 972 https://doi.org/10.1083/jcb.201102042

37. MARTIJN J, ETTEMA TJG 2013 From archaeon to eukaryote: The evolutionary dark ages of the eukaryotic cell. Biochem Soc Trans 41: 451-457 https://doi.org/10.1042/BST20120292

38. WIDEMAN JG, LEUNG KF, FIELD MC, DACKS JB 2014 The cell biology of the endocytic system from an evolutionary perspective. Cold Spring Harb Perspect Biol 6: a016998 https://doi.org/10.1101/cshperspect.a016998

39. KOONIN EV 2015 Origin of eukaryotes from within archaea, archaeal eukaryome and bursts of gene gain: Eukaryogenesis just made easier? Phil Trans R Soc Lond B Biol Sci 370: 20140333 https://doi.org/10.1098/rstb.2014.0333

40. SCHÖNHEIT P, BUCKEL W, MARTIN WF 2016 On the origin of heterotrophy. Trends Microbiol 24: 12-25 https://doi.org/10.1016/j.tim.2015.10.003

41. MARTIN W, MÜLLER M 1998 The hydrogen hypothesis for the first eukaryote. Nature 392: 37-41 https://doi.org/10.1038/32096

42. DACKS JB, FIELD MC, BUICK R, EME L, GRIBALDO S, ROGER AJ, BROCHIER-ARMANET C, DEVOS DP 2016 The changing view of eukaryogenesis - Fossils, cells, lineages and how 
they all come together. J Cell Sci 129: 3695-3703

https://doi.org/10.1242/jcs. 178566

43. CAVALIER-SMITH T 1989 Molecular pylogeny. Archaebacteria and Archezoa. Nature 339: 100-101 https://doi.org/10.1038/339100a0

44. KEELING PJ 1998 A Kingdom's progress: Archezoa and the origin of eukaryotes. Bioessays 20: 87-95

https://doi.org/10.1002/(SICI)1521-1878(199801)20:1<87::AIDBIES12>3.0.CO;2-4

45. EMBLEYTM, MARTIN W 2006 Eukaryotic evolution, changes and challenges. Nature 440: 623-630 https://doi.org/10.1038/ nature04546 https://doi.org/10.1038/nature04546

46. FOX GE, STACKEBRANDT E, HESPELL RB, GIBSON J, MANILOFF J, DYER TA, WOLFE RS, BALCH WE, TANNER RS, MAGRUM LJ, ZABLEN LB, BLAKEMORE R, GUPTA R, BONEN L, LEWIS BJ, STAHL DA, LUEHRSEN KR, CHEN KN, WOESE CR 1980 The phylogeny of prokaryotes. Science 209: 457-463 https://doi.org/10.1126/science.6771870

47. VAN VALEN LM, MAIORANA VC 1980 The Archaebacteria and eukaryotic origins. Nature 287: 248-250 https://doi.org/10.1038/287248a0

48. SEARCY DG 1992 Origins of mitochondria and chloroplasts from sulphurbased symbioses. In: Hartman H, Matsuno K (eds) The origin and evolution of the cell. World Scientific, Singapore, pp 47-78

49. VELLAI T, VIDA G 1999 The origin of eukaryotes: The difference between prokaryotic and eukaryotic cells. Proc Biol Sci 266: 15711577 https://doi.org/10.1098/rspb.1999.0817

50. THEISSEN U, HOFFMEISTER M, GRIESHABER M, MARTIN W 2003 Single eubacterial origin of eukaryotic sulfide:quinone oxidoreductase, a mitochondrial enzyme conserved from the early evolution of eukaryotes during anoxic and sulfidic times. Mol Biol Evol 20: $1564-1574$ https://doi.org/10.1093/molbev/msg174

51. SEARCY DG 2003 Metabolic integration during the evolutionary origin of mitochondria. Cell Res 13: 229-238 https://doi.org/10.1038/sj.cr.7290168

52. OLSON KR, STRAUB KD 2016 The role of hydrogen sulfide in evolution and the evolution of hydrogen sulfide in metabolism and signaling. Physiology (Bethesda) 31:60-72 https://doi.org/10.1152/physiol.00024.2015

53. WHATLEY JM, JOHN P, WHATLEY FR 1979 From extracellular to intracellular: The establishment of mitochondria and chloroplasts. Proc R Soc Lond B 204: 165-187 https://doi.org/10.1098/rspb.1979.0020

54. LANE N, MARTIN W 2010 The energetics of genome complexity. Nature 467: 929-934. https://doi.org/10.1038/nature09486

55. SOUSA FL, NEUKIRCHEN S, ALLEN JF, LANE N, MARTIN WF 2016 Lokiarchaeon is hydrogen dependent. Nat Microbiol 1: 16034 https://doi.org/10.1038/nmicrobiol.2016.34

56. MARTIN WF, NEUKIRCHEN S, ZIMORSKI V, GOULD SB, SOUSA FL 2016 Energy for two: New archaeal lineages and the origin of mitochondria. Bioessays 38: 850-856 https://doi.org/10.1002/bies.201600089

57. SCHINK B 1997 Energetics of syntrophic cooperation in methanogenic degradation. Microbiol Mol Biol Rev 61: 262-280

58. MÜLLER M, MENTEL M, VAN HELLEMOND JJ, HENZE K, WOEHLE C, GOULD SB, YU R-Y, VAN DER GIEZEN M, TIELENS AGM, MARTIN WF 2012 Biochemistry and evolution of anaerobic energy metabolism in eukaryotes. Microbiol Mol Biol Rev 76: 444-495 https://doi.org/10.1128/MMBR.05024-11

59. DA CUNHA V, GAIA M, GADELLE D, NASIR A, FORTERRE P 2017 Lokiarchaea are close relatives of Euryarchaeota, not bridging the gap between prokaryotes and eukaryotes. PLoS Genet 13: e1006810 https://doi.org/10.1371/journal.pgen.1006810
60. RINKE C, SCHWIENTEK P, SCZYRBA A, IVANOVA NN, ANDERSON IJ, CHENG JF, DARLING A, MALFATTI S, SWAN BK, GIES EA, DODSWORTH JA, HEDLUND BP, TSIAMIS G, SIEVERT SM, LIU WT, EISEN JA, HALLAM SJ, KYRPIDES NC, STEPANAUSKAS R, RUBIN EM, HUGENHOLTZ P, WOYKE T 2013 Insights into the phylogeny and coding potential of microbial dark matter. Nature 499: 431-437 https://doi.org/10.1038/nature12352

61. WILLIAMS TA, EMBLEY M 2014 Archaeal 'dark matter' and the origin of eukaryotes. Genome Biol Evol 6: 474-481 https://doi.org/10.1093/gbe/evu031

62. THIERGART T, LANDAN G, MARTIN WF 2014 Concatenated alignments and the case of the disappearing tree. BMC Evol Biol 14: 266 https://doi.org/10.1186/s12862-014-0266-0

63. LOCKHART PJ, HOWE CJ, BARBROOK AC, LARKUM AWD, PENNY D 1999 Spectral analysis, systematic bias, and the evolution of chloroplasts. Mol Biol Evol 16: 573-576 https://doi.org/10.1093/oxfordjournals.molbev.a026139

64. MARTIN WF 2017 Physiology, anaerobes, and the origin of mitosing cells 50 years on. J Theor Biol 434: 2-10 https://doi.org/10.1016/j.jtbi.2017.01.004

65. GRAY MW, DOOLITTLE WF 1982 Has the endosymbiont hypothesis been proven? Microbiol Rev 46: 1-42

66. VOSSBRINCK CR, MADDOX JV, FRIEDMAN S, DEBRUNNER-VOSSBRINCK BA, WOESE CR 1987 Ribosomal RNA sequence suggests microsporidia are extremely ancient eukaryotes. Nature 326: 411-414 https://doi.org/10.1038/326411a0

67. SOGIN M, GUNDERSON J, ELWOOD H, ALONSO R, PEATTIE D 1989 Phylogenetic meaning of the kingdom concept: An unusal ribosomal RNA from Giardia lamblia. Science 243: 75-77 https://doi.org/10.1126/science.2911720

68. ANDERSSON SGE, KURLAND CG 1999 Origins of mitochondria and hydrogenosomes. Curr Opin Microbiol 2: 535-541 https://doi.org/10.1016/S1369-5274(99)00013-2

69. STAIRS CW, ROGER AJ, HAMPL V 2011 Eukaryotic pyruvate formate lyase and its activating enzyme were acquired laterally from a firmicute. Mol Biol Evol 28: 2087-2099 https://doi.org/10.1093/molbev/msr032

70. STAIRS CW, EME L, BROWN MW, MUTSAERS C, SUSKO E, DELLAIRE G, SOANES DM, VAN DER GIEZEN M, ROGER AJ 2014 A SUF Fe-S cluster biogenesis system in the mitochondrion-related organelles of the anaerobic protist Pygsuia. Curr Biol 24: 1176-1186 https://doi.org/10.1016/j.cub.2014.04.033

71. STAIRS CW, LEGER MM, ROGER AJ 2015 Diversity and origins of anaerobic metabolism in mitochondria and related organelles. Philos Trans R Soc Lond B Biol Sci 370: 20140326 https://doi.org/10.1098/rstb.2014.0326

72. LEGER MM, EME L, HUG LA, ROGER AJ 2016 Novel hydrogenosomes in the microaerophilic jakobid Stygiella incarcerata. Mol Biol Evol 33: 2318-2336 https://doi.org/10.1093/molbev/msw103

73. EME L, GENTEKAKI E, CURTIS B, ARCHIBALD JM, ROGER AJ 2017 Lateral gene transfer in the adaptation of the anaerobic parasite Blastocystis to the gut. Curr Biol 27: 807-820 https://doi.org/10.1016/j.cub.2017.02.003

74. MARTIN WF 2017 Too much eukaryote LGT. Bioessays in press. https://doi.org/10.1002/bies.201700115

75. MENTEL M, MARTIN W 2008 Energy metabolism among eukaryotic anaerobes in light of Proterozoic ocean chemistry. Philos Trans R Soc Lond B 363: 2717-2729 https://doi.org/10.1098/rstb.2008.0031

76. DEGLI ESPOSTI M 2014 Bioenergetic evolution in proteobacteria and mitochondria. Genome Biol Evol 6: 3238-3251 https://doi.org/10.1093/gbe/evu257 
77. MARTIN WF 2017 Unmiraculous facultative anaerobes (comment on DOI 10.1002/bies.201600174). Bioessays 39: in press https://doi.org/10.1002/bies.201700041

78. PARFREY LW, LAHR DJG, KNOLL AH, KATZ LA 2011 Estimating the timing of early eukaryotic diversification with multigene molecular clocks. Proc Natl Acad Sci U S A 108: 13624-9. https://doi.org/10.1073/pnas.1110633108

79. LYONS TW, REINHARD CT, PLANAVSKY NJ 2014 The rise of oxygen in earth's early ocean and atmosphere. Nature 506: 307-315 https://doi.org/10.1038/nature13068

80. TAYLOR FRJ 1974 Implications and extensions of the serial endosymbiosis theory of the origin of eukaryotes. Taxon 23: 229-258 https://doi.org/10.2307/1218702

81. CAVALIER-SMITH T 1975 The origin of nuclei and of eukaryotic cells. Nature 256: 463-468 https://doi.org/10.1038/256463a0

82. BAUM DA, BAUM B 2014 An inside-out origin for the eukaryotic cell. BMC Biol 12: 76 https://doi.org/10.1186/s12915-014-0076-2

83. MARTIN W 1999 A briefly argued case that mitochondria and plastids are descendants of endosymbionts, but that the nuclear compartment is not. Proc R Soc Lond B 266: 1387-1395 https://doi.org/10.1098/rspb.1999.0792

84. SOUBANNIER V, MCLELLAND GL, ZUNINO R, BRASCHI E, RIPPSTEIN P, FON EA, MCBRIDE HM 2012 A vesicular transport pathway shuttles cargo from mitochondria to lysosomes. Curr Biol 22: 135-141 https://doi.org/10.1016/j.cub.2011.11.057

85. CAVALIER-SMITH T 1987 The simultaneous symbiotic origin of mitochondria, chloroplasts and microbodies. Ann N Y Acad Sci 503: 55-71 https://doi.org/10.1111/j.1749-6632.1987.tb40597.x

86. BOLTE K, RENSING SA, MAIER UG 2015 The evolution of eukaryotic cells from the perspective of peroxisomes: Phylogenetic analyses of peroxisomal beta-oxidation enzymes support mitochondria-first models of eukaryotic cell evolution. Bioessays 37: 195-203 https://doi.org/10.1002/bies.201400151

87. SPEIJER D 2017 Evolution of peroxisomes illustrates symbiogenesis. Bioessays 39: in press https://doi.org/10.1002/bies.201700050

88. SUGIURA A, MATTIE S, PRUDENT J, MCBRIDE HM 2017 Newly born peroxisomes are a hybrid of mitochondrial and ERderived pre-peroxisomes. Nature 542: 251-254 https://doi.org/10.1038/nature21375

89. HETTEMA EH, GOULD SJ 2017 Cell biology: Organelle formation from scratch. Nature 542: 174-175 https://doi.org/10.1038/nature21496

90. AEBI M $2013 \mathrm{~N}$-linked protein glycosylation in the ER. Biochim Biophys Acta 1833: 2430-2437 https://doi.org/10.1016/j.bbamcr.2013.04.001

91. NOTHAFT H, SZYMANSKI CM 2013 Bacterial protein Nglycosylation: New perspectives and applications. J Biol Chem 288: 6912-6920 https://doi.org/10.1074/jbc.R112.417857

92. JARRELL KF, DING Y, MEYER BH, ALBERS SV, KAMINSKI L, EICHLER J $2014 \mathrm{~N}$-linked glycosylation in archaea: A structural, functional, and genetic analysis. Microbiol Mol Biol Rev 78: 304-341 https://doi.org/10.1128/MMBR.00052-13

93. BLACKSTONE NW 2013 Why did eukaryotes evolve only once? Genetic and energetic aspects of conflict and conflict mediation. Phil Trans R Soc B Biol Sci 368: 20120266 https://doi.org/10.1098/rstb.2012.0266

94. DOLEZAL P, LIKIC V, TACHEZY J, LITHGOW T 2006 Evolution of the molecular machines for protein import into mitochondria. Science 313, 314-318 https://doi.org/10.1126/science.1127895

95. SCHLEIFF EE, BECKER TT 2011 Common ground for protein translocation: Access control for mitochondria and chloroplasts. Nat Rev Mol Cell Biol 12: 48-59 https://doi.org/10.1038/nrm3027
96. ALLEN JF 2003 The function of genomes in bioenergetic organelles. Philos Trans R Soc Lond B 358: 19-37 https://doi.org/10.1098/rstb.2002.1191

97. MARTIN W, HOFFMEISTER M, ROTTE C, HENZE K 2001 An overview of endosymbiotic models for the origins of eukaryotes, their ATP-producing organelles (mitochondria and hydrogenosomes) and their heterotrophic lifestyle. Biol Chem 382: 1521-1539 https://doi.org/10.1515/BC.2001.187

98. JUDSON OP 2017 The energy expansions of evolution. Nat Ecol Evol 1: 138 https://doi.org/10.1038/s41559-017-0138

99. LANE N, MARTIN WF 2015 Eukaryotes really are special, and mitochondria are why. Proc Natl Acad Sci U S A 112: E4823 https://doi.org/10.1073/pnas.1509237112

100. BOOTH A, DOOLITTLE WF 2015 Reply to Lane and Martin: Being and becoming eukaryotes. Proc Natl Acad Sci U S A 112: E4824 https://doi.org/10.1073/pnas.1513285112

101. LANE N, MARTIN WF 2016 Mitochondria, complexity, and evolutionary deficit spending. Proc Natl Acad Sci U S A 113: E666 https://doi.org/10.1073/pnas.1522213113

102. LYNCH M, MARINOV GK 2016 Reply to Lane and Martin: Mitochondria do not boost the bioenergetic capacity of eukaryotic cells. Proc Natl Acad Sci U S A 113: E667-E668 https://doi.org/10.1073/pnas.1523394113

103. LYNCH M, CONERY JS 2003 The origins of genome complexity. Science 302: 1401-1404 https://doi.org/10.1126/science.1089370

104. LYNCH M 2007 The frailty of adaptive hypotheses for the origins of organismal complexity. Proc Natl Acad Sci U S A 104: 85978604 https://doi.org/10.1073/pnas.0702207104

105. FENCHEL T 2014 Respiration in heterotrophic unicellular eukaryotic organisms. Protist 165: 485-492 https://doi.org/10.1016/j.protis.2014.05.006

106. RICH PR, MARÉCHAL A 2010 The mitochondrial respiratory chain. Essays Biochem 47: 1-23 https://doi.org/10.1042/bse0470001

107. CHRÉTIEN D, BÉNIT P, HA HH, KEIPERT S, EL-KHOURY R, CHANG YT, JASTROCH M, JACOBS HT, RUSTIN P, RAK M 2017 Mitochondria are physiologically maintained at close to $50{ }^{\circ} \mathrm{C}$. BioRxiv https://doi.org/10.1101/133223

108. HELDAL M, NORLAND S, TUMYR O 1985 X-ray microanalytic method for measurement of dry matter and elemental content of individual bacteria. Appl Environ Microbiol 50: 1251-1257

109. HAROLD FM 1986 The vital force: a study of bioenergetics. WH Freeman, New York

110. POLAKIS ES, BARTLEY W 1966 Changes in dry weight, protein, deoxyribonucleic acid ribonucleic acid and reserve and structural carbohydrate during the aerobic growth cycle of yeast. Biochem J 98: 883-887 https://doi.org/10.1042/bj0980883

111. HOURCADE D, DRESSLER D, WOLFSON J 1973 The amplification of ribosomal RNA genes involves a rolling circle intermediate. Proc Natl Acad Sci U S A 70: 2926-2930 https://doi.org/10.1073/pnas.70.10.2926

112. MCGRATH CL, KATZ LA 2004 Genome diversity in microbial eukaryotes. Trends Ecol Evol 19: 32-38 https://doi.org/10.1016/j.tree.2003.10.007

113. KOBAYASHI $\mathrm{T} 2011$ Regulation of ribosomal RNA gene copy number and its role in modulating genome integrity and evolutionary adaptability in yeast. Cell Mol Life Sci 68: 1395-1403 https://doi.org/10.1007/s00018-010-0613-2

114. FARQUHAR GD, VON CAEMMERER S, BERRY JA 1980 A biochemical model of photosynthetic $\mathrm{CO} 2$ assimilation in leaves of C3 species. Planta 149: 78-90 https://doi.org/10.1007/BF00386231 
115. LIN MT, OCCHIALINI A, ANDRALOJC PJ, PARRY MAJ, HANSON MA $2014 \mathrm{~A}$ faster Rubisco with potential to increase photosynthesis in crops. Nature 513: 547-550 https://doi.org/10.1038/nature13776

116. GARG SG, MARTIN WF 2016 Mitochondria, the cell cycle, and the origin of sex via a syncytial eukaryote common ancestor. Genome Biol Evol 8: 1950-1970 https://doi.org/10.1093/gbe/evw136

117. GARCIA-SEISDEDOS H, EMPEREUR-MOT C, ELAD N, LEVY ED 2017 Proteins evolve on the edge of supramolecular self-assembly. Nature 548: 244-247 https://doi.org/10.1038/nature23320

118. MARTIN W, KOONIN EV 2006 Introns and the origin of nucleus-cytosol compartmentalization. Nature 440: 41-45 https://doi.org/10.1038/nature04531

119. SENDER R, FUCHS S, MILO R 2016 Revised estimates for the number of human and bacteria cells in the body. PLoS Biol 14: e1002533 https://doi.org/10.1371/journal.pbio.1002533

120. KEELING PJ, MCCUTCHEON JP, DOOLITTLE WF 2015 Symbiosis becoming permanent: Survival of the luckiest? Proc Natl Acad Sci U S A 112: 10101-10103 https://doi.org/10.1073/pnas.1513346112

121. MARTIN W 2011 Early evolution without a tree of life. Biol Direct 6: 36 https://doi.org/10.1186/1745-6150-6-36

122. WHITMAN WB, COLEMAN DC, WIEBE WJ 1998 Prokaryotes: The unseen majority. Proc Natl Acad Sci U S A 95: 65786583 https://doi.org/10.1073/pnas.95.12.6578

123. NEI M 2013 Mutation-Driven Evolution. Oxford University Press, Oxford

124. MARTIN W, HERRMANN RG 1998 Gene transfer from organelles to the nucleus: how much, what happens, and why? Plant Physiol 118: 9-17 https://doi.org/10.1104/pp.118.1.9

125. TIMMIS JN, AYLIFFE MA, HUANG CY, MARTIN W 2004 Endosymbiotic gene transfer: Organelle genomes forge eukaryotic chromosomes. Nat Rev Genet 5: 123-135. https://doi.org/10.1038/nrg1271

126. HAZKANI-COVO E, COVO S 2008 Numt-mediated double strand break repair mitigates deletions during primate genome evolution. PLoS Genet 4: e1000237

https://doi.org/10.1371/journal.pgen.1000237

127. ESSER C, AHMADINEJAD N, WIEGAND C, ROTTE C, SEBASTIANI F, GELIUS- DIETRICH G, HENZE K, KRETSCHMANN E, RICHLY E, LEISTER D, BRYANT D, STEEL MA, LOCKHART PJ, PENNY D, MARTIN W 2004 A genome phylogeny for mitochondria among alpha-proteobacteria and a predominantly eubacterial ancestry of yeast nuclear genes. Mol Biol Evol 21: 1643-1660 https://doi.org/10.1093/molbev/msh160

128. THIERGART T, LANDAN G, SCHENK M, DAGAN T, MARTIN WF 2012 An evolutionary network of genes present in the eukaryote common ancestor polls genomes on eukaryotic and mitochondrial origin. Genome Biol Evol 4: 466-485 https://doi.org/10.1093/gbe/evs018

129. COTTON JA, MCINERNEY JO 2010 Eukaryotic genes of archaebacterial origin are more important than the more numerous eubacterial genes, irrespective of function. Proc Natl Acad Sci U S A 107: 17252-17255 https://doi.org/10.1073/pnas.1000265107

130. KU C, NELSON-SATHI S, ROETTGER M, GARG S, HAZKANI-COVO E, MARTIN WF 2015 Endosymbiotic gene transfer from prokaryotic pangenomes: Inherited chimerism in eukaryotes. Proc Natl Acad Sci U S A 112: 10139-10146 https://doi.org/10.1073/pnas.1421385112

131. HUANG CY, AYLIFFE MA, TIMMIS JN 2003 Direct measurement of the transfer rate of chloroplast DNA into the nucleus. Nature 422: 72-76 https://doi.org/10.1038/nature01435
132. BENSASSON D, ZHANG D, HARTL DL, HEWITT GM 2001 Mitochondrial pseudogenes: Evolution's misplaced witnesses. Trends Ecol Evol 16: 314-321 https://doi.org/10.1016/S0169-5347(01)02151-6

133. HAZKANI-COVO E, MARTIN WF 2017 Quantifying the number of independent organelle DNA insertions in genome evolution and human health. Genome Biol Evol 9: 1190-1203 https://doi.org/10.1093/gbe/evx078

134. KEELING PJ, MCCUTCHEON JP 2017 Endosymbiosis: The feeling is not mutual. J Theor Biol 434, 75-79 https://doi.org/10.1016/j.jtbi.2017.06.008

135. HUSNIK F, MCCUTCHEON JP Repeated replacement of an intrabacterial symbiont in the tripartite nested mealybug symbiosis. Proc Natl Acad Sci U S A 113: E5416-E5424 https://doi.org/10.1073/pnas.1603910113

136. HUANG CY, GRÜNHEIT N, AHMADINEJAD N, TIMMIS JN, MARTIN W 2005 Mutational decay and age of chloroplast and mitochondrial genomes transferred recently to angiosperm nuclear chromosomes. Plant Physiol 138: 1723-1733 https://doi.org/10.1104/pp.105.060327

137. MARTIN W 2003 Gene transfer from organelles to the nucleus: Frequent and in big chunks. Proc Natl Acad Sci U S A 100: 8612-8614 https://doi.org/10.1073/pnas.1633606100

138. ANDERSSON JO 2005. Lateral gene transfer in eukaryotes. Cell Mol Life Sci 62: 1182-1197. https://doi.org/10.1007/s00018-005-4539-z

139. GOGARTEN JP 2003 Gene transfer: Gene swapping craze reaches eukaryotes. Curr Biol 13: R53-R54 https://doi.org/10.1016/S0960-9822(02)01426-4

140. KEELING PJ, PALMER JD 2008 Horizontal gene transfer in eukaryotic evolution. Nat Rev Genet 9: 605-618 https://doi.org/10.1038/nrg2386

141. PITTIS AA, GABALDÒN T 2016 Late acquisition of mitochondria by a host with chimaeric prokaryotic ancestry. Nature 531: 101-104 https://doi.org/10.1038/nature16941

142. MARTIN WF, ROETTGER M, KU C, GARG SG, NELSONSATHI S, LANDAN G 2017 Late mitochondrial origin is an artifact. Genome Biol Evol 9: 373-379 https://doi.org/10.1093/gbe/evx027

143. MADIGAN MT, MARTINKO JM, BENDER KS, BUCKLEY DH, STAHL DA 2012 Brock Biology of Microorganisms, 13th edn. Benjamin Cummings, Boston

144. MARCET-HOUBEN M GABALDÓN T 2010 Acquisition of prokaryotic genes by fungal genomes. Trends Genet 26: 5-8 https://doi.org/10.1016/j.tig.2009.11.007

145. SZOELLOSI GJ, DAVIN AA, TANNIER E, DAUBIN V 2015 Genome-scale phylogenetic analysis finds extensive gene transfer among fungi. Phil Trans R Soc Lond B Biol Sci 370: 20140335 https://doi.org/10.1098/rstb.2014.0335

146. BOOTHBY TC, TENLEN JR, SMITH FW, WANG JR, PATANELLA KA, NISHIMURA EO, TINTORI SC, LI Q, JONES CD, YANDELL M, MESSINA DN, GLASSCOCK J, GOLDSTEIN B 2016 Evidence for extensive horizontal gene transfer from the draft genome of a tardigrade. Proc Natl Acad Sci U S A 112: 15976-81 https://doi.org/10.1073/pnas.1510461112

147. KU C, MARTIN WF 2016 A natural barrier to lateral gene transfer from prokaryotes to eukaryotes revealed from genomes: The $70 \%$ rule. BMC Biol 14: 89 https://doi.org/10.1186/s12915-016-0315-9

148. DAGAN T, ARTZY-RANDRUP Y, MARTIN W 2008 Modular networks and cumulative impact of lateral transfer in prokaryote genome evolution. Proc Natl Acad Sci U S A 105: 1003910044 https://doi.org/10.1073/pnas.0800679105 
149. NELSON-SATHI S, DAGAN T, LANDAN G, JANSSEN A, STEEL M, MCINERNEY JO, DEPPENMEIER U, MARTIN WF 2012 Acquisition of 1,000 eubacterial genes physiologically transformed a methanogen at the origin of Haloarchaea. Proc Natl Acad Sci U S A 109: 20537-20542 https://doi.org/10.1073/pnas.1209119109

150. NELSON-SATHI S, SOUSA FL, ROETTGER M, LOZADACHÁVEZ N, THIERGART T, JANSSEN A, BRYANT D, LANDAN G, SCHÖNHEIT P, SIEBERS B, MCINERNEY JO, MARTIN WF 2015 Origins of major archaeal clades correspond to gene acquisitions from bacteria. Nature 517: 77-80 https://doi.org/10.1038/nature13805

151. ECK RV, DAYHOFF MO 1966 Evolution of the structure of ferredoxin based on living relics of primitive amino acid sequences. Science 152: 363-366 https://doi.org/10.1126/science.152.3720.363

152. MOREIRA D, LÓPEZ-GARCÍA P 1998 Symbiosis between methanogenic archaea and $\delta$-proteobacteria as the origin of eukaryotes: The syntrophic hypothesis. J Mol Evol 47: 517-530 https://doi.org/10.1007/PL00006408

153. FORTERRE P 2011 A new fusion hypothesis for the origin of Eukarya: Better than previous ones, but probably also wrong. Res Microbiol 162: 77-79 https://doi.org/10.1016/j.resmic.2010.10.005

154. DE DUVE C 2007. The origin of eukaryotes: A reappraisal. Nat Rev Genet 8: 395-403 https://doi.org/10.1038/nrg2071

155. DESCHAMPS P 2014 Primary endosymbiosis: Have cyanobacteria and Chlamydiae ever been roommates? Acta Soc Bot Poloniae 83: 291-302 https://doi.org/10.5586/asbp.2014.048

156. DOMMAN D, HORN M, EMBLEY TM, WILLIAMS TA 2015 Plastid establishment did not require a chlamydial partner. Nat Comm 6: 6421. https://doi.org/10.1038/ncomms7421

157. GUY L, SAW JH, ETTEMA TJG 2014 The archaeal legacy of eukaryotes: A phylogenomic perspective. Cold Spring Harb Per- spect Biol 6: a016022

https://doi.org/10.1101/cshperspect.a016022

158. LOPEZ-GARCIA P, EME L, MOREIRA D 2017 Symbiosis in eukaryotic evolution. J Theor Biol 434: 20-33 https://doi.org/10.1016/j.jtbi.2017.02.031

159. MARGULIS L, CHAPMAN M, GUERRERO R, HALL J 2006 The last eukaryotic common ancestor (LECA): acquisition of cytoskeletal motility from aerotolerant spirochetes in the Proterozoic Eon. Proc Natl Acad Sci U S A 103: 13080-13085. https://doi.org/10.1073/pnas.0604985103

160. SCHWARTZ RM, DAYHOFF MO 1978 Origins of prokaryotes, eukaryotes, mitochondria, and chloroplasts. Science 199: 395-403 https://doi.org/10.1126/science.202030

161. AANEN DK, EGGLETON P 2017 Symbiogenesis: Beyond the endosymbiosis theory? J Theoret Biol 434: 99-103 https://doi.org/10.1016/j.jtbi.2017.08.001

162. MARTIN W 1999 Mosaic bacterial chromosomes: a challenge en route to a tree of genomes. BioEssays 21: 99-104 https://doi.org/10.1002/(SICI)1521-1878(199902)21:2<99::AIDBIES3>3.0.CO;2-B

163. GOULD SB, MAIER U-G, MARTIN WF 2015 Protein import and the origin of red complex plastids. Curr Biol 25: R515-R521 https://doi.org/10.1016/j.cub.2015.04.033

164. WEISS MC, SOUSA FL, MRNJAVAC N, NEUKIRCHEN S, RÖTTGER M, NELSON- SATHI S, MARTIN WF 2016 The physiology and habitat of the last universal common ancestor. Nature Microbiol 1:16116.

https://doi.org/10.1038/nmicrobiol.2016.116

165. BRUSINA S 1904 Zur Rettung unserer Mollusken-Fauna. (On saving our molluscan fauna.) Nachrichtenblatt der deutschen Malakozoologischen Gesellschaft 36: 157-168 [German]

166. RAUCH C, JAHNS P, TIELENS AGM, GOULD SB, MARTIN WF 2017 On being the right size as an animal with plastids. Front Plant Sci 8: 1402 https://doi.org/10.3389/fpls.2017.01402 